\title{
Bir Yemek Kitabından Neler Öğrenilir? Leman Cılızoğlu’nun Yemek Pişirme Temel Metod ve Uygulama Beslenme Yemek Görgü Kuralları Kitabı Üzerinden Bir İnceleme
}

\author{
Şengül İnce ${ }^{1}$ (다
}

Öz

Kitaplar, fotoğraflar, yazmalar, resmi evrak, devlet kayıtları, mektuplar, anılar, günlükler ve otobiyografi geçmişi okumak ve anlamak için kullanılan temel kaynaklardır. Bütün bunların dışında geçmişi anlamak için bir mutfakta olması gereken tenceretava çeşidini, garnitür hazırlamanın metodlarını, iyi bir patates kızartmasının püf noktalarını, pilav yemenin görgü kurallarını ya da etli taze baklanın nasıl yapıldığını anlatan bir yemek kitabı bir araştırmacıya nasıl yardımcı olabilir, bir yemek kitabından neler öğrenilebilir? Bu sorunun cevabını düşünmek, geçmişi anlamak için başvurulan kaynakların ve büyük anlatıların dışına çıkıp gündelik hayatın sıradan, önemsiz ve ideolojiden uzak görünen bir alanı olarak mutfak üzerine düşünmeyi sağlar. Mutfak, gündelik hayatın bir parçası olarak ev ve mutfak, mutfak ekipmanı, gıda ve tarım politikaları, yemek ve yemek kültürleri, üretim ve tüketim, toplumsal cinsiyet ilişkileri ve tüm bunlardaki değişimi görmeye olanak verir. Yemek kitapları bu bağlamda, mutfağı kayıt altına alan ve geriye dönük olarak okumaya olanak veren kaynaklar olarak değerlendirilmektedir. Çıkış noktası yukarıdaki soru olan bu çalışmada 1971 yılında Leman Cilızoğlu tarafindan yazılan Yemek Pişirme Temel Metod ve Uygulama Beslenme Yemek Görgü Kuralları adlı kitap incelenerek bir yemek kitabının içinde bulunan yemeklerin, tariflerin yapısının, gıdanın, yemek pişirilen mekân olarak mutfağın, mutfağın donanımının geçmiş hakkında neler söyleyebileceğine dair giriş niteliğinde betimleyici bir çalışma yapılandırılmıştır.

Anahtar Kelimeler: Yemek kitabı • Mutfak • Tarifler • Gündelik hayat • Leman Cılızoğlu • Yemek Pişirme Temel Metod ve Uygulama Beslenme Yemek Görgü Kuralları

What Can Be Learned from a Cookbook: An Analysis of Leman Cilızoğlu's The Fundamental Methods and Application of Food and Cooking: Nutrition, Food, Rules of Good Manners

Abstract

Books, photographs, manuscripts, legal documents, public records, letters, memoirs, diaries, and autobiographies are the primary resources used for examining and understanding the past. Apart from these, is it possible to understand the past through kitchens and what sorts of pots were used, the methods for preparing side dishes, the best way to fry potatoes, the manners about eating rice or the broad bean with meat, the proper way to prepare cranberry jam? And how can a cookbook that gives details about all of these things help a researcher? Thinking about the answers to these questions leads one to leave the grand narratives and classical resources to take a look at the kitchen as a part of everyday life, a mundane, unimportant space removed from ideology. Kitchens provide the opportunity to examine kitchenware, food, agriculture policies, food cultures, production and consumption, gender relations, and the changes in all of these. In such a context, cookbooks are understood as resources that document all of this throughout time and provide a basis through which to examine a past period. Driven by the above questions analyzed through Leman Cilızoğlu's (1971) cookbook Yemek Pişirme Temel Metod ve Uygulama Beslenme Yemek Görgü Kuralları [The Fundamental Methods and Application of Food and Cooking: Nutrition, Food, Rules of Good Manners], this descriptive paper is structured over understanding and discussing what cookbooks can say by analyzing the book's content, the structure of the recipes, the kitchen as a space for cooking and food, and the content of kitchens.

Keywords: Cookbooks • Kitchen • Recipes • Everyday life • Leman Cilızoğlu • Yemek Pişirme Temel Metod ve Uygulama Beslenme Yemek Görgü Kuralları

1 Şengül İnce (Dr. Öğr. Üyesi), Hacettepe Üniversitesi, Illetişim Fakültesi, İletişim Bilimleri Bölümü, Kültürlerarası Illetişim Anabilim Dalı, Ankara, Türkiye. Eposta: ince.sengul@gmail.com ORCID: 0000-0001-5277-9966

Atıf: İnce, S. (2020). Bir yemek kitabından neler öğrenilir? Leman Cılızoğlu’nun Yemek Pişirme Temel Metod ve Uygulama Beslenme Yemek Görgü Kuralları Kitabı üzerinden bir inceleme. İstanbul Üniversitesi Sosyoloji Dergisi, 40, 365-396. https:// doi.org/10.26650/SJ.2020.40.1.0033-2 


\section{Extended Summary}

Cookbooks seem to belong to the kitchen, which is seen as an unimportant part of everyday life. For this reason, the use of cookbooks as historical material for understanding a situation or a period of time is possible by recognizing the importance of the ordinary. By focusing importance on the unimportant and unworthy, new subjects of interest have emerged in the dominant scientific approach, as well as new resources and new techniques to study these. In such a context, cookbooks have become an alternative resource for understanding a period of time and its socio-cultural texture. As Barbara Wheaton noted (2009, p. 3), whether handwritten or printed, cookbooks that transfer recipes, knowledge, and experience related to the kitchen offer surprises and trophies for the careful reader. Anne Willian et al. (2012) defined cookbooks as a recipe collection for creating meals, while Henry Notaker views cookbooks as books that provide information about the cuisine and recipes at a ratio of $40 \%-50 \%(2012$, p. 2$)$.

Wheaton $(2009$, p. 3$)$ views cookbooks as a magical hat in which you can get more than you expect if you are a careful reader, pointing to the fact that these are peculiar cultural artifacts that can be helpful if they are read by taking into consideration the context in which they were produced. Similarly, Driver $(2015$, p. 15) stated that cookbooks reflect various aspects of the past and tell a story about the time in which they were written in. Cookbooks are likely to be used as resources to determine the cultural, political, and economic structures of the society in which the cookbook is produced, as Wheaton's and Driver's arguments indicate. For example, Mennel et al. (1995) see these books as an archive that documents domestic history, whereas Tobias (1998) goes beyond domestic history stating that these provide clues about social history. Brownlee, Hewer, and Horne (2005) stated cookbooks to be cultural artifacts that contain written cultural stories; they are the cultural creators of the kitchen (Tonner, 2008 , p. 5). These sorts of studies are closely related to the discipline of history and set examples for using cookbooks as historical documents. On the other hand, Ken Albala (2013, p. 116) points to cookbooks, recipe ingredients, cooking methods, and service types for examining gender roles. Other studies on cookbooks involve discussing food culture and the traces of identity (Chen, 2014; Voski Avakian, 2005); gender roles (Theophano, 2002; Bower, 1997; Neuhaus, 1999); nationalism and the formation of nation states (Appadurai, 1988; Gold, 2006; Ichijo \& Ranta, 2018); community, ethnicity, migration, and diasporic communities (Monstragelo, 2015; Black, 2010; Epp, 2015); and memory.

The aim of this study is to analytically examine one cookbook in order to see what can be learned from a cookbook in our attempt to understand the cultural, political, and economic history of Turkey's geographical region and to see holistically the analytic categories that result from this analysis. The cookbook The Fundamental Methods and Application of Food and Cooking: Nutrition, Food, Rules of Good Manners by Leman 
C1lızoğlu (1970), which has been reprinted several times over the years, has been selected for this study for determining these categories and examining what these categories and their content tell us about living in a particular period. One important reason for choosing this book for analysis is that the book not only aims to provide recipes and cooking techniques but also consists of other issues. The target group for this cookbook is determined to be all housewives without any clear discrimination, and the things they are supposed to know are included in the content. In this respect, the book doesn't focus on a particular cuisine, recipes from a particular chef, urban cooking, or the food prepared in wealthy households. As such, the book has a wider scope. This cookbook from C1lızoğlu, who was a teacher at the Girls’ Art Teacher School [K1z Sanat Öğretmen Okulu], is an educational book that contains information about the importance of food, suggestions for a healthy and balanced diet, the nutritional values for food, how to supply and store food, home economics, how to prepare and serve special meals, and the rules for consuming these meals. In such a context, this book is neither a recipe book nor a book on manners. Just like the other books prepared by the teachers from the Girls' Institutes and Girls' Art Schools, this book consists of the various sections that can be found in separate cookbooks all in one book. This characteristic of consisting of various sections is one of the primary reasons for choosing this book in order to find out what categories shed light on the cultural, economic, and political circumstances of the time in which the book was written. In this respect, the book is seen as a useful resource for examining various issues related to food. Among the many cookbooks written by teachers from Girls' Institutions, this book by C1lızoğlu is the one of the most well-known ones that has been reprinted several times.

The name of the book, the chapter orders, the total number of pages, the number of pages designated to each chapter, the recipes, the ingredients used in the recipes, the description of the kitchen and its wares, organizing the table, and suggestions regarding manners are the main focal points of the examination. As a result of this examination, C1lızoğlu's cookbook can be said to have contributed to the formation of a homogeneous modern and universal cuisine that excludes ethnic, regional, and national references by not providing any geographical markers or any particular ethnic cuisine-based cooking practices or local ingredients, instead pointing to so-called Western standards for cooking. The cookbook positions women as the leading actor for running home economics and for establishing and maintaining solidarity in the family and the happy ideal society as a manifestation of the objective women's institutions had for forming modern society. As a result, the language of the book is didactical and rule based. It aims to provide the checklist of the rules that should be obeyed in order to organize private life in line with the objectives of the modern state: planning and maintaining order. In other words, these rules are "innocent" ideological tools that aimed to lead the modern women of the nation state. When taking into consideration previous research, just like the other grand narratives and the institutions 
of a particular period of time, the cookbooks can be said to have likely been used as a tool of modernization for forming the nation state and social change for the "great objectives" of the state and tpolitical power. In this respect, Crlızoğlu's cookbook can be said to have likely been a tool of the modernization project at a particular period in Turkey's history for forming an ideal society and for putting this responsibility on the shoulders of women in the private sphere. 


\section{Bir Yemek Kitabından Neler Öğrenilir? Leman Cılızoğlu’nun Yemek Pişirme Temel Metod ve Uygulama Beslenme Yemek Görgü Kuralları Kitabı Üzerinden Bir İnceleme}

"Yemek kitaplarl, arzuların, korkuların ve umutlarm belgesidir." (Humble'dan aktaran Gold, 2007, s. II)

\section{Başlarken}

Yemek kitapları, sıradan ve görünmez olarak nitelendirilen gündelik hayatın en önemsiz atfedilen kısmı olan mutfağa aittir. Bu nedenle de yemek kitaplarının herhangi bir durumu ve dönemi anlamak için tarihsel bir malzeme olarak kullanılması, gündelik olanın öneminin anlaşılması ile mümkün olmuştur. Gündelik hayat, "kendini tekrar eden", “sıkıcı", "bıktırıcı", “önemsiz” ve “değersiz” olarak nitelendirilen pratiklerin ve eylemlerin alanı olarak büyük ve önemli görülen konularla ilgilenen hakim bilim anlayışı içinde uzunca bir süre kendine yer bulamamıştır. Ancak makro teorilerin ve büyük anlatıların 20. yüzyılda dünyada olup biteni anlama konusunda yetersiz kalması, o güne kadar dışarıda bırakılan bireye ve eylemlerine, ürünlerine, gündelik hayatına yani kültürüne odaklanmayı beraberinde getirdi. Bu yeni anlayış, geçmişi, içinde bulunulan zamanı anlamak ve geleceğe dair öngörülerde bulunmak için kullanacağ1 yeni kaynakları ve metodları da geliştirdi. Makro tarih anlatısında siyaset odaklı tarihten insan faaliyetlerinin tamamına odaklanan bir tarih anlayışını başlatan Annales Okulu'nun ${ }^{1}$, tarihte olup biteni anlamak için geliştirdiği disiplinlerarası yaklaşım, devlet arşivleri dışında kaynak olarak görülebilecek her tür materyalin başvuru kaynağ1 olarak kullanılmasının önünü açarken ${ }^{2}$ mikro tarihçilerin sıradan insana ve yerele yaptıkları vurgu, bireysel deneyimlere odaklanmayı ve sözlü tarih çalışmalarını beraberinde getirdi ${ }^{3}$. Bu bağlamda yemek kitapları da önemli bir kaynak olarak araştırmacıların ilgisini çekmeye ve üzerinde çalışılmaya başlandı.

Tarihin ilk dönemlerinden bu yana tariflerin yer aldığı kil tabletler, el yazması ve basılı kitaplar hatta emek emek her denemenin ardından yazıya geçirilen bazen de anne-anneanne tariflerinin yeni bir mutfağa transfer olmasıyla kuşaklar arasında deneyim ve tarif aktarımı sağlayan tarif defterleri, Barbara Wheaton’un söylediği gibi dikkatli okuyucularını sürprizler ve ödüllerle karşılayabilecek bir niteliğe sahiptir. Yemek kitaplarının sihirli bir şapka olduğunu ve içindekilerden çok daha fazlasının

1 Annales Okulu'nun çalışmaları hakkında ayrıntılı bilgi için bkz: Peter Burke (2006) Fransız Tarih Devrimi Annales Okulu, Ankara: Doğu Batı Yayınları.

2 Nüfus kayıtları, nüfus sayımları ve hareketleri, mahkeme tutanakları, kilise kayıtları, üretim verileri, ürün ve hizmet fiyatları ve hareketleri, satış sözleşmeleri, kral kararnameleri, destan, şiir, şarkı sözleri vs.

3 Türkiye sosyal bilim camiasının çalışmalarında Annales Okulu'nun 1950'lerde ve ikinci bir dalga olarak 1980'lerde (Kayalı, 2006, s.13-18), mikro tarih ve gündelik hayat çalışmalarının 1980'lerden sonra etkili olmaya başladığını söylemek yanlış olmaz. 
elde edilebileceğini ifade eden Wheaton, bu kültürel artifactlerin olağandışı (peculiar) dökümanlar olduğunu, üretildiği zaman ve mekân bağlamında okunursa, geçmişi anlamak için çok kullanışlı olabileceğini belirtir $(2009$, s. 3). Benzer şekilde Driver da (2015) yemek kitaplarının geçmişin pek çok yönünü yansıttığını ve yazıldıkları zaman hakkında bir hikâye anlattığını ifade eder (s.15). Wheaton'un ve Driver'ın ifadelerinden yola çıkarak yemek kitaplarının içinden çıktı̆̆ toplumun kültürel, politik ve ekonomik yapısına dair çeşitli saptamalar yapmak için kullanılabilecek bir kaynak olduğu anlaşılmaktadır.

Bu çalışmanın amacı, bir yemek kitabını, yaşadığımız coğrafyanın kültürel, politik, ekonomik geçmişini anlamak için, yemek kitaplarından neler öğrenebileceğimize dair analitik incelemeye tabi tutmak ve ortaya çıkacak analitik kategorileri holistic (bütüncül) bir şekilde görmektir. Bu analitik kategorileri belirlemek ve kategoriler altında kitabın yazıldığı döneme dair hangi bilgilere ulaşılabildiğini ortaya koyabilmek için Leman Cılızoğlu tarafından 1970 yılında yazılan ve sonraki yıllarda pek çok baskısı yapılan Yemek Pişirme Temel Metod ve Uygulama Beslenme Yemek Görgü Kuralları kitabı seçilmiştir. Bu kitabın seçilmesinin nedenlerinden biri, kitabın sadece yemek tarifleri ve yemek pişirme teknikleri bilgisi için hazırlanmamış olmasıdır. Hedef kitlesinin "tüm ev kadınları" olarak belirlendiği ve onların bilmek zorunda olduğu düşünülen bilgilere yer verilen kitapta, sadece aşçıların, belli bir etnik grubun, şehirde yaşayanların ve zengin evlerin mutfaklarında pişirdikleri yemeklere ve onların mutfaklarına odaklanılmamış bu nedenle de kapsayıcılığı geniş bir kitap olarak değerlendirilmiştir. Akşam Kız Sanat Okulu öğretmeni olan Leman C1lızoğlu'nun kitabı, beslenmenin önemi, sağlıklı ve dengeli beslenme önerileri, yiyeceklerin besin değerleri, yiyeceklerin alınması ve saklanması, ev idaresi, mutfak ve günlük öğünler dışında özel zamanlarda hazırlanacak yiyecekler ve bunların nasıl servis edileceğine ve tüketileceğine dair kurallar hakkında bilgiler vermek amacıyla hazırlanmış bir eğitim kitabıdır. Bu bağlamda kitap, sadece bir yemek kitabı ya da sadece bir adab-1 muaşeret kitabı değildir. Kitap, kapsamlı konu başlıklarıyla farklı türden yemek kitaplarının içindekiler bölümünde yer alan başlıkları içinde toplayacak şekilde hazırlanmıştır. Cılızoğlu'nun kitabı, içindeki bilgilerin, yazıldığı dönemin kültürel, ekonomik ve politik durumu hakkında analiz yapmaya pek çok kategorinin ortaya çıkartılmasına olanak verecek çeşitlilikte olması, yemek kitapları üzerinden çalışılabilecek pek çok konu bağlamında kullanılabilecek bir kaynak olduğu için çalışma için örnek olarak seçilmiştir. Ayrıca yayınlandığı tarihten bu yana pek çok baskısı yapılmış olan kitap, Kız Enstitüleri ve onunla aynı dönemde benzer görevleri paylaşan diğer eğitim kurumlarının kadın öğretmenleri tarafından yazılan kitaplar arasında günümüzde en çok bilinen kitaplar arasındadır. 


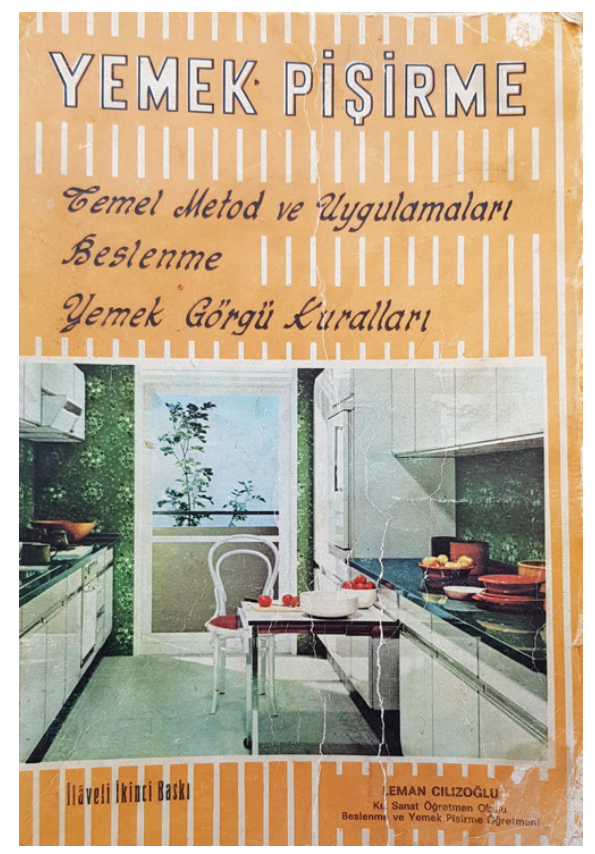

Görsel 1. Leman C1lızoğlu'nun kitabının kapak sayfası.

\section{Yemeklerin Kitabı}

Her ne kadar tartışmalı olduğunu ifade etse de Goody, yemek pişirme ile ilgili ilk çalışmanın tarihini milattan önce ikinci yüzyıla kadar götürür ${ }^{4}$ (Goody, 2013, s. 136). 1844 yılında bir tıp hocası olan Mehmed Kamil tarafından yazılan Melceü't Tabbahin ise Osmanlı İmpratorluğu'ndaki ilk yemek kitabı olarak tarihe geçer. Bu kitabın ardından Aşçıların Sığınă̆ı, Yeni Yemek Kitabı, Ev Kadını ve Aşçıbaşı ile devam eden yemek kitaplarının sayısı 1927 yılına kadar 40'1 geçer ${ }^{5}$ (Samanc1, 2014, s. 22). Bu yüzyılla birlikte başlayan yemek kitapları literatürü, günümüze kadar gittikçe zenginleşir ve çeşitlenir. Örneğin bazı yemek kitapları, temel pişirme teknikleri ve klasik tarifler için kullanılacak referans kitaplar olarak hazırlanmıştır. Bazıları, belli bir grup için özelleştirilmiş çalışmalardır. Belirli bir hastalık nedeniyle yapılan diyetler, yaşlılar veya çocuklar için hazırlanan kitaplar bu türe örnek olarak gösterilebilir. Günümüzde belli bir cemaatin, göçmen ve etnik grubun yemeklerine yer verilen topluluk yemek kitapları

4 Goody, ilk kitapların Atheaneus'un 200 yılında yazdığı ve mutfakla ilgili ilk bilimsel çalışma The Deipnosophists ve Apicius'un hazırladığı eserler olduğunu ifade eder (Goody, 2013, s. 136-137).

5 Samancı, Tanzimat Dönemi ile basılmaya başlayan bu kitaplarda Osmanlı İmpratorluğu'nda başlayan batılılaşma hareketlerinin etkisi ile Avrupa mutfağının etkisinin görülmeye başlandığını ve kitaplarda alaturka ve alafranga yemeklerin birarada görüldüğünü ifade etmiştir. Osmanlı Türkçesi dışında İmparatorluk sınırları içinde yaşayan Ermeniler de yine 19. yüzyıl sonunda Ermeni harfli Türkçe yemek kitapları basmıştır (Samanc1, 2014, s. 22-23). 
(community cookbook) ile belirli bir yörenin ya da bölgenin adına atıfta bulunan etnografik nitelikli kitaplar ise yemek kitapları literatürünün bir başka örneğidir. Ünlü şeflerin ve aşç1ların (bu gruba başka alanlarda ismi duyulmuş-ünlü isimler de dahil edilebilir) hazırladıkları kitaplar da sık sık raflarda karşılaşılan yemek kitaplarındandır.

Yemek kitab1, Anne Willian vd. tarafindan bir tarifler koleksiyonu olarak yemek yaratmak için kullanılan bir pişirme taslağı şeklinde tanımlanırken Henry Notaker ise yemek kitabını, mutfak hakkında genel bilgi veren ve en azından \%40-50'si tarif içeren kitaplar olarak tanımlar (2012 s. 2). Ancak yemek kitaplarının sadece yemek pişirmeye yardımcı olan bir içeriğe sahip olduğunu söylemek bu literatüre haksızlık olur. Bu bağlamda sorulması gereken soru, bir yemek kitabından yemekler ve pişirme usulleri dışında neler öğrenilebileceğidir? Bu soruya Mennell ve arkadaşları (1985), yemek kitaplarının domestik tarihi anlatmak üzere kullanılabilecek bir arşiv oluğunu göstererek cevap verir. Tobias (1998) ise domestik tarihin ötesine giderek yemek kitaplarının geniş bir toplumsal tarih için ipucu verebileceğini ileri sürer. Brownlee, Hewer ve Horne (2005) ise kültürel bir artifact olarak yemek kitaplarının yazılı kültürel hikâyeler içerdiğini ve bunların mutfak kültürünün yaratıcıları olarak anlaşılabileceğini ifade eder (Tonner, 2008, s. 5). Bu tür çalışmalar yemek kitapları ile tarih disiplinini doğrudan ilişkilendirir ve yemek kitaplarının tarihi bir döküman olarak nasıl kullanılacağını örnekler. Bu bağlamda Wessell de tarihi kaynaklar olarak yemek kitaplarının, mutfak mirasını temsil ederek geçmişe anlam verdiğini belirtir. Priscilla Mary Işın da (2018) benzer şekilde, Yemeğin Kültürel Tarihi adlı çalışmasının Giriş bölümünde "Yediğimiz yemek ve yiyeceklerin hepsi geçmişi yansıtır." ifadesi ile yiyecekler, yemek ve geçmiş arasında bir ilişki kurar.

Yemek kitaplarının toplumsal tarihi anlamak için kullanılabileceğini düşünen Wheaton, bu kitapların en fazla tariflerde yer alan malzemeler-içindekiler (ingredients) hakkında birşeyler söyleyeceğini, tariflerde kullanılan gıdaların dökümünün, o kültürde kullanılan gıdalarla karşılaştırılabileceğini ve böylece o ülkenin yılın belli zamanlarındaki beslenme ve yeme alışkanlıkları, yoksul ve zengin mutfakları hakkında ipuçları vereceğini söyler (Wheaton, s. 3). Ken Albala da yemek kitaplarını, toplumsal cinsiyet rollerini, tariflerin içindekilerinin, pişirme metodlarının ve servis türlerinin toplumsal anlamlarını anlamak ve gıda maddelerinin global ticaretle marketlerde geçerli hale gelmesinin izini sürmek için incelenebileceğini belirtir (Albala, 2013, s. 116).

Yemek ve yemek kitapları üzerinden oluşan literatüre kısa bir bakış bile bu kitapların bir ülkenin beslenme rejiminin, yemek kültürünün ve yiyeceklerin yerel ve küresel bağlamda izini sürmek, kimlik (Chen, 2014, Voski Avakian, 2005), toplumsal cinsiyet rolleri (Theophano, 2002; Bower, 1997, Neuhaus, 1999), milliyetçilik ve uluslaşma (Appadurai, 1988; Gold, 2006, Ichijo ve Ranta, 2018), cemaat, etnisite, göç, diasporik topluluklar (Monstragelo, 2015; Black, 2010; Epp, 2015) ve bellek gibi konular1 
çözümlemek ve anlamak için kullanılan kaynaklardan biri olduğunu anlamayı sağlar. $\mathrm{Bu}$ örneklerle, Carol Gold'un da belirttiği gibi (2007), yemek kitaplarında geleneksel olarak mutfağın dışına yerleştirilen politik, toplumsal ve ideolojik konuları ve bunlardaki değişimlerin işaretlerini görmek mümkündür. Yemek kitabının, yazıldığı dönemin sosyal koşulları ve trendleri ile ilgili olduğunu belirten Chen, bu kitapların yemek pişirme ile ilgili özel alandaki know-how (bilgi birikimini) havuzlarını kamusal alana taşıdığını ifade eder (Chen, 2014, s. 491-492). Dolayısıyla yemek kitapları, özel ve kamusal alan arasında ilişki kuran ve bu iki alanda olup biteni yansıtan bir kaynak olarak oldukça kullanışlıdır.

Türkiye'de yemek kültürü hakkında dolayısıyla mutfak, gıda ve yemek üzerine yapılan çalışmaların Annales Okulu'nun Türkiyeli araştırmacılar üzerinde etkisinin görüldügü 1950 'li y1llara kadar götürmek mümkündür. Osmanl1-Türk gida çalışmalarındaki önemli çalışmalara değindiği yazısında Samancı, 1950'li yıllar itibariyle ekonomi tarihçilerinin çalışmaları, folklor ve Türkoloji çalışmaları bağlamında gıda tarihi ile ilgili çalışmaların arttığını belirtir. Osmanlı İmpratorluğu'nun son zamanlarında gıda arzı ve çeşitliliği, gıda tedarik zinciri, ticaret ve pazarlar, Osmanlı elitinin yemek pişirme alışkanlıkları, yemekleri ve saray mutfağının organizasyonuna dair çalışmalar yapıldığını ve bu çalışmalarda saray kayıtlarının, mutfak sicillerinin ve vakıf belgelerinin kullanıldığını ifade eder (Samancı, 2013, s. 107-109). Bir tıp tarihçisi olan Süheyl Ünver'in 18. yüzyıla ait olan tarifleri topladığı Fifty Turkish Dishes in History adlı kitabı, Burhan Oğuz'un folklor çalışmaları içinde yer alan 1976 tarihli Anadolu insanın gıda tüketim örüntülerini anlattığı çalışması, Bahattin Ögel'in Orta Asya'da yaşadıkları zamanlardan bu yana Türklerin mutfağını incelediği çalışması (1978), Milli Folklor Araştırma Dairesi’nin 1980'li yıllar itibariyle Türk Mutfağının kökeninin konuşulduğu, yurt dışına tanıtımının yapıldığı ve özel tatlarının sergilendiği sempozyumlar mutfak, yemek ve gıdanın üzerine odaklanan diğer çalışmalardandır. Türkoloji çalışmaları ise bu coğrafyada eski dilde yazılan yemek el yazmaları, mutfakla ilgili belgeleri ve kitaplarını Türkçeye çevirerek araştırmacılar için yeni kaynaklar sunmuştur ${ }^{6}$. Dini törenler, özel günler, eğlenceler ve kutlamalarda verilen yemekler ve içerikleri ile bunların servisine dair kayıtların incelenmesi de Osmanlı yemek araştırmalarında önemli kaynaklar olmuştur. Ayrıca imparatorluk toprakları içinde yaşayan azınlıkların yemek kitapları da Osmanlı mutfağının çok kültürlü ve çok etnikli yapısını anlamak için çevirileri yapılarak (Mükemmel Yemek Kitabı, Aşçının Yemek Kitabl) ilgilenenlere sunulmuştur (Samanc1, 2013, s. 109-112). Samanc1 2000'li yıllar itibariyle Osmanlı ve Türk yemek kültürü ve mutfağındaki tariflere ve tatlara odaklanan çalışmalar yapıldığını ve sosyo kültürel yaklaşımla yapılan çalışmaların başladığına

6 Türkoloji çalışmaları içinde kaynak çevirilerinin yanısıra (Sefercioğlu, 1985; Kut) eski dilde yayınlanan yemek el yazmaları ve kitaplarının bibliyografyası hazırlanmış (Kut, 1985), Bağdadi tarafından yazılan bir el yazmasının 15. yüzyılda Şirvani tarafından tercüme edilmesi ve yeni tariflerin eklenmesi ile Osmanlı dünyasında bilinen ilk yemek el yazmasının çevirisi yapılmıştır (bkz. Samancı, 2013) 
işaret eder ${ }^{7}$. Bu çalışmalardan Osmanlı-Türk Mutfă̆ı Üzerine Bir Değerlendirme: Yemek Kitaplarında Alaturka-Alafranga İkiliği (2014) adlı çalışmasında Özge Samancı, Osmanlı İmparatorluğu'nda Tanzimat döneminde Osmanlı Türkçesi ile daha sonra Latin harfleri ile 1960'lı y1llara kadar basılan kitaplarda alaturka alafranga ikiliğini ve iki dönem arasında yer alan yemeklerdeki farklılı̆̆ 1 anlatır . Acar Tek ve Sürücüoğlu tarafından "Basılmış Olan İlk Türk Yemek Kitabı: Melceü’t Tabbahin” adıyla yapılan çalışma da kitabın içinde yer alan tarifler ve kitabın İngilizce çevirisi hakkında bilgi vermektedir. Osmanlı ve Modern Türkiye'deki yiyecek ve içecek kültürüne odaklanan çalışmasında Samancı (2019), modern Türkiye'deki yiyecek içecek kültürünün Osmanlı'nın devamı olduğunu İmparatorluğun başkenti İstanbul'da saray mutfağında kullanılan yiyecekler, içecekler, özel gün yemekleri, İstanbul halkının yeme içme alışkanlıkları ve buradaki yiyecek içecek çeşitliliği ve ticareti üzerinde durmaktadır.

\section{Yemek Kitaplarıyla Çalışmak}

Tarihi okumak için alternatif bir kaynak olarak yemek kitaplarını kullanmak verimli olmakla birlikte Wessel'in de belirttiği gibi (2013) bir dedektif gibi dikkatli ve titiz bir çalışmayı gerektirir. Yazıldığı dönemi ve geçmişi anlamak için başvuru niteliğinde olsa da Wheaton'ın “kural koyucu” olarak adlandırdığı bu literatürün geçmişi araştırmak için kırılgan bir yapısı bulunmaktadır (2009, s. 3). Araştırmacıların bu kırılgan yapının farkında olarak inceledikleri kitapların içinde yer alanların, yazıldıkları dönemdeki ve gündelik hayattaki karşılığına odaklanmaları gerekmektedir. Wheaton, eski bir yemek kitabını okumanın muhteşem olduğunu, iki kitabı aynı anda okumanın karşılaştırma yapma imkânı sunduğunu ama üç ya da dördünü birden okumanın, nerede ne olduğunu hatırlamak ve bunların karşılaştırmasını yapmak bakımından çok zor olduğunu ifade eder (Wheaton, 2014, s. 277). Yemek kitapları ile çalışmanın bir başka zorluğu, bu kural koyucu literatür ile gerçeklik arasında bağ kurmanın her zaman kolay olmamasıdır. Wheaton, kitaplarda çok fazla göstermelik (showpiece) tarif bulunduğunu ve bunların gerçekte pişirilenden fazlasına denk geldiğini, gündelik hayatta çok fazla malzemeli ve komplike tariflerin karşılığını bulmadığının altını çizer (Wheaton, 2014, s. 278). Benzer şekilde Albala da tarihi bir yemek kitabıyla çalışırken unutulmaması gereken en önemli şeylerden birinin, bu kitapların nadiren insanların gerçekte ne yediklerini kaydetmiş olduğu gerçeği olduğunu belirtir. Tarihi yemek kitapları, bazen yenen yemeklerin menülerini kaydeder ama çoğunlukla tanımlayıcı olmaktan çok kuralcıdır.

7 Osmanlı'da alkol tüketiminin ve kimlikle ilişkisi, Osmanlı egemenliğindeki Yunanlıların mutfak kültürü ve Osmanlı sarayında gıdanın anlamı, saray mutfağı ve halka yemek veren vakıflar üzerine yapılan çalışmalar sosyokültürel yaklaşımla yapılmış çalışmalar arasındadır. Ayrıca Osmanlı İmparatorluğu'nun farkı dönemlerini içine alarak yemek-gıda ve tıp, yemek ve politika, yemek dağıtan vakıflar, yiyecek tüketim örüntüleri ve kimlik (Tülay Artan) üzerinde duran çalışmalar da Osmanlı-Türk yemek çalışmalarındandır (bkz. Samancı, 2013).

8 Bu çalışmada Samancı, belirtilen dönemlerde çıkan yemek kitaplarında batının yemeklerinin etkisinin görülmeye başlandığını özellikle Fransız yemeklerinin alaturka yemeklerle birlikte kitaplarda yer aldığını, Cumhuriyet dönemi ile birlikte Fahriye Nedim ve Ekrem Muhittin Yeğen tarafından hazırlanan kitapların da içeriğinin yine aynı çizgide olduğuna işaret eder (bkz. Samancı. 2014). 
$\mathrm{Bu}$ durumda araştırmacılar, ellerindeki yemek kitabının, yazarın değerleri ve ideallerini ve belki de bu kitabı alabilecek okuyucuların değer ve ideallerini yansıtabileceğini akılda tutmalıdır. Yemek kitapları literatürü ile ilgli bu saptama aslında yemek kitaplarının belli bir amaç doğrultusunda yazıldığını ortaya koyar. Ama bu ön bilgi hiçbir zaman, insanların nasıl pişirdiğinin ve ne yediklerinin kesin bir kanıtının olamayacağı anlamına gelmez (Albala, 2013, s.117).

Albala, çok geniş bir bilgi kaynăğ olduğunu düşündüğü yemek kitapları ile çalışırken öncelikle araştırmacının bu metinlerden ne öğrenmek istediğini ortaya koyması gerektiğini belirtir (2013, s. 117). Yemek kitaplarının çok fazla tekrar, gıda ve teknik bilgi içerdiği için okunmasının oldukça zor olduğunu ifade eden Wheaton ve Albala, yemek kitaplarına sistematik bir şekilde yaklaşmanın gerekli olduğunu ifade eder (2014, s. 276, 2013, s. 117). Wheaton, yemek kitabı incelemesi yaparken bir kitabın bütününe bakmak yerine öncelikle tek bir tarafina bakmayı ve birbiri ile ilişkili bir grup kitabı bu şekilde incelemeyi önerir. Bu bağlamda tariflerdeki malzemelerin envanterini yapmak ve kalitelerini ele almak, yemeğin anlatımındaki pişirme tekniklerini incelemek, mutfağ ve içindeki ekipmanı görmek ve son olarak servis ve yeme davranışlarını incelemek geçmiş zamanlarda ve mekânlarda yiyecek hazırlama ve yemek yemenin toplumsal hareketlerini anlamaya zemin hazırlar (2014, s. 277). Bu çalışmada, Wheaton ve Albala'nın yemek kitapları üzerine çalışılırken belirledikleri başlıklar dikkate alınarak Leman C1lızoğlu tarafından hazırlanan ve 1971 yılında ikinci baskısı yapılan Yemek Pişirme Temel Metod ve Uygulamaları Beslenme Yemek Görgü Kuralları (ilave İkinci Baskı) kitabı incelenmektedir. Bu inceleme, kitabın adı, sayfa sayısı, baskı teknolojisi, görsel kullanımı, amacı, işaret ettiği hedef kitle, mutfak ve mutfak ekipmanı, tarifler, tariflerde kullanılan malzemeler, masa düzeni ve öneriler üzerinden gerçekleştirilmiştir.

\section{Adını Söyle Nasıl Bir Kitap Olduğunu Söyleyeyim!}

Herhangi bir kitabı elimize aldığımızda yaptığımız ilk iş, kitabın başlığına, kapağına, yazarına, arka kapağına, fiyatına, giriş ve içindekiler bölümüne odaklanmaktır. $\mathrm{Bu}$ durum, bir yemek kitabı için de farklı değildir. Bir yemek kitabının adı ile içeriği genellikle okuyucularını şaşırtmaz hatta içeriği hakkında ciddi ipuçları verir. Kitabın ismi, kitabın bölgesel, etnik veya ulusal karakterli olup olmadığını veya belli bir diyet için mi hazırlandığını ortaya koyabilir. Kitabın ismi ve tarif başlıkları, o mutfağın temel yiyeceği ve yemeği hakkında, Appadurai'nin ifade ettiği gibi kültürün "gıda temelli karakteri” (Appadurai, 1988, s. 16) hakkında bilgiler sağlayabilir. Bölgesel ya da etnik karakterli yemek kitapları, o kültürlerin yemeklerine ve genel özelliklerine yabancı olanlar için hazırlanır. Örneğin, Gaziantep Mutfağı adı ile basılan bir yemek kitab1, bu mutfağın yiyeceklerine, yemeklerine ve hazırlama yöntemlerine aşina olmayanlar için hazırlanmış bir çalışmadır. Bu bağlamda okuyucular, diğer bölgesel 
ve etnik mutfaklardan farklılaşan yönleriyle ve kültürleriyle Gaziantep mutfağını, temel gıda maddelerini, hazırlama ve pişirme yöntemlerini ve menülerini tanıma şansını elde ederler. Böylece okur, örneğin Gaziantep mutfağının anlatıldığı bir yemek kitabının içindekiler bölümünde temel malzemesi et olmasına rağmen kebaplar ve et yemekleri gibi iki farklı başlık gördüğünde mutfağın karakteristiğini ve temel malzemesinin et olduğunu farkeder. İncelediğimiz yemek kitabına bu bağlamda baktığımızda kitabın adından başlayarak herhangi bir mutfağa özellikle yapılan bir vurgudan bahsetmenin söz konusu olmadığı görülür. Yemek Pişirme Temel Metod ve Uygulamaları Beslenme Yemek Görgü Kuralları adı ile yayınlanan kitap, aynı adla başka herhangi bir coğrafyada yayınlanabilir. Bu tespit, tariflerin topluca görüldüğü içindekiler bölümü incelendiğinde de değişmez. Kitapta yer alan tariflerin isimlerinin, bugün pek çok yemek kitabının işaret ettiği gibi herhangi bir etnik gruba, bölgeye ya da ulusal karaktere referansta bulunmadığı görülür. Yemek kitaplarında hiç bir ayırıcı ve farklılaştırıcı isim ve malzemenin bulunmaması, bölgesel ve etnik farklılıkların belirsizleştirilmesi, homojen bir mutfak yaratma çabasının ürünüdür. Böylece mutfak, yemek ve gıda aracıllğıyla etnik ve bölgesel farkl1lıkları görünmez kılan evrensel ve modern değerlerle hazırlanmış bir mutfak kültürü yaratılmaya çalış1lır'.

Driver bir kitap incelemesi sırasında yazarın kimliğinin, özellikle cinsiyetinin, eğitiminin, sosyal statüsünün, dininin, etnik kökeni ve dilinin kitabın yaratılmasında anahtar bir faktör olduğunu ayrıca yazar olarak bir vakıfın, derneğin ya da şirket adının bulunup bulunmadığına bakmanın gerekliliğine işaret eder (2015, s. 258). Wheaton da (2009) bir yemek kitabının yazarının doğum tarihi ya da yaş bilgisinin de kitabın yazılış amacını ortaya koymada oldukça işe yarar olduğunu ifade eder. Wheaton bu bilginin yazarın kitabı, geleceği düşünerek mi yoksa geçmişi korumak için mi yazdığını ortaya çıkabileceğini düşünür. Çalışmaya konu olan kitabın eğitim ve yardımcı bir kitap olarak tasarlanması, yazarın öğretmen olması, hedef kitlesinin kadınlar olarak işaret edilmesi kitabın halihazırdaki alışkanlıkları değiştirme ve geleceği biçimlendirme amacıyla yazıldığını gösterir. Eğer yazar, "kaybolmaya yüz tutmuş", "değişmeye başlamış" "çocukluğuna ait" "miras" tariflerden derlediği bir kitapla karşımızdaysa bu çalışmanın geçmişe sahip çıkma amacı ile yazıldığı düşünülebilir. İncelenen kitap daha önce de belirtildiği gibi kadın bir öğretmen tarafından, bir eğitim kurumunun ismi verilerek ve farklı eğitim kurumlarının müfredatına uygun bir şekilde kadınların eğitimi için hazırlanmış mevcut durumu ve geleceği biçimlendirmeye yönelik bir kitaptır.

Kitabın isminden sonra dikkat edilecek bir başka öğe kapak tasarımıdır. İncelenen kitabın, turuncu rengin hakim olduğu kapak sayfasında duvarları beyaz dolaplarla kaplı,

9 Benzer şekilde Cumhuriyet modernleşmesinde mimari de bir araç olarak kullanılmış ve hedeflenen toplumsal dönüşümleri meşrulaştırmak için bölgesel ve etnik farklılıkları görünmez kılan ve geçmişin izlerini silmeye çalışan, sadeliğin ön planda olduğu modern bir mimari tarzı benimsenmiştir (ayrıntılı bir çalışma için bkz, Sibel Bozdoğan (2015). Modernizm ve Ulusun İnşası Erken Cumhuriyet türkiyesinde Mimari Kültür, İstanbul: Metis. 
siyah tezgâhlı ve bir çalışma masasının bulunduğu renkli bir mutfak görseli bulunmaktadır. Bu mutfak, 1920'lerde ortaya çıkan ve mutfakları bir laboratuvar gibi planlayan Frankfurt mutfağını andırmaktadır. Kadının en az enerjiyi harcaması ve zamanının çok az kısmını burada geçirmesi için verimlilik esasına göre planlanan bu mutfaklar, Türkiye coğrafyasında bu görselde karşılığını bulmuştur. Bu mutfak görselinde firın, ocak ve buzdolabı gibi elektronik aletler, tezgâh içine (ankastre) yerleştirilmiştir. 1970'ler Türkiye'sinde Frankfurt mutfağının ve ankastre kullanımının yaygınlaşmadığını ve kapakta yer alan görselin bir ideali yansıttığını söylemek yanlış olmaz. Bu, Cumhuriyetin modern evinin modern mutfak idealinin görselleştirilmiş halidir.

Kapak sayfasından sonra önsöz ve reklam sayfası olarak kullanılan son sayfalar da dahil olmak üzere 519 sayfadan oluşan kitap, daha çok bir ansiklopedi niteliği taşımaktadır. Bu özelliğiyle kitap, bir raf ya da kenarda unutulmaktan ziyade kendine mutfakta özel bir yer açacak nitelikte görünmektedir. Günümüzde yemek kitapları, okuyucularını rengârenk bir kapak ve içeriğindeki görsel şölenle karşılar. Kitabın içinde yer alan yiyeceklerin renkleri ve yemeklerin görselleri, okuyucuları cezbederek kitapları görünür kılarken aynı zamanda iştah kabartır. Son zamanlarda gelişen teknoloji, yemek kitaplarının sadece okunan değil aynı zamanda izlenilen bir forma dönüşmesine olanak vermekte kitapların içine yerleştirilen kare kodlar, okuyucuları, yemeğin hazırlanma aşamasını izlemesini sağlayacak videolara yönlendirmektedir. Bütün bunlar basım teknolojisinde gelinen aşamalar hakkında araştırmacılara bilgi verir. İncelenen yemek kitabının kapağından başlayarak bu türden bir analiz yapıldığında renk öğesine sadece kapakta ve kitabın içine yerleştirilmiş olan bir reklam broşüründe rastlandığını söylemek mümkündür. Kitabın içinin, siyah beyaz baskı teknolojisi kullanılarak hazırlanmış olması, renkli baskının bu dönemde basım sektörü için pahalı bir uygulama olduğunu ve kitabın maliyetini düşürmek için siyah beyaz baskının kullanıldığını düşündürtmektedir. Bu durum, basım teknolojisinin durumu hakkında bilgi verebileceği gibi hitap edilen kitlenin alım gücü üzerine düşünmeyi gerektirir. Hedef kitlesi geniş olan bir kitabın, alınabilir fiyata satılması gerekir.

Kitapta hem elle çizilmiş şemalara, masa düzenleri, yemek ve yemeğin hazırlanma aşamasını gösteren siyah beyaz fotoğraflara hem de hazır grafik çizimlere yer verilmiştir. Bugün baskı teknolojisinin ve tasarımın geldiği noktada kitaplarda farklı görsel formatların bulunması yerine tek bir görsel format tercih edilmekte ve özellikle konu yemek kitabı olduğunda görsellerin kalitesi ve rengi çok önemli olmakta bu nedenle editör, tasarımcı, çizer, fotoğrafçı, basımcı ve yayıncıdan oluşan kalabalık bir ekip, kitabı basım aşamasına hazırlamaktadır. Cılızoğlu'nun kitabında iç kapağı ve Önsöz bölümündeki teşekkürler kısmını inceleyince kitabın sadece görselleri hazırlayan bir teknik ressam ve yazar tarafından hazırlandığı anlaşı1ır. 


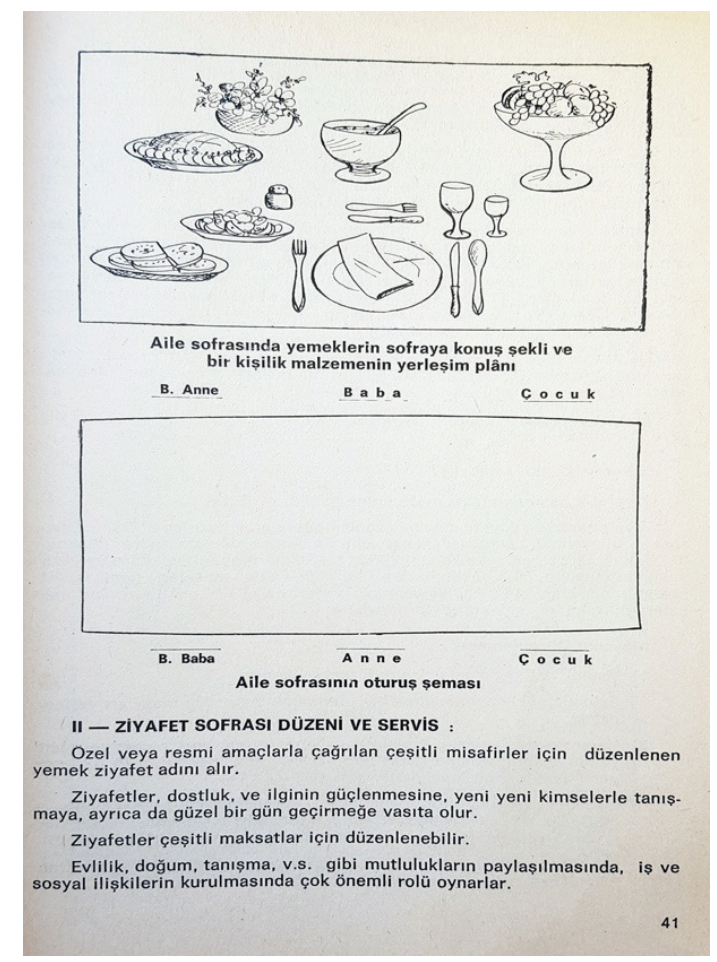

Görsel 2. Leman Cılızoğlu'nun kitabının Sofra Düzenleri Servis Bölümü’nde aile sofrasının düzenlenme biçiminin anlatıldığı çizim.

Kitap, hem Kız Sanat Öğretmen Okulu ve Akşam Sanat Okulları öğrencileri için hem de tüm ev kadınları için hazırlanmıştır. Dolayısıyla kitaba okul dışında ulaşmak isteyenlerin nasıl ulaşacağı da önemli bir konudur. Leman C1lızoğlu'nun kitabına bu gün sahaflar aracıllğ 1 ile online olarak ulaşılabilmektedir. Ancak o dönemde okuyucuların kitaba ulaşımı için kitabın iç sayfasında Ankara Bahçelievler'de bir posta kutusu adresi bir de yazarın açık ev adresi isteme adresi olarak verilmiştir. Kitaba bunun dışında nerelerde erişilip erişilmediğine dair bir bilgi bulunmamaktdır. Bu durum, kitabın yazıldığı dönemde kitap dağııım ağının durumu hakkında araştırmacıyı düşünmeye itecek bir durumdur. Kitapla ilgili dikkat edilmesi gereken noktalardan biri de kaç adet basıldığı, kaçıncı kez basıldığı, basımlar arasında herhangi bir farklılık olup olmadığı (eklemeler, çıkarmalar), reklamının nasıl yapıldığı ve nasıl satıldığıdır (Driver, 2015, s. 259).

Kitapta bölüm kapak sayfaları dışında 87 görsel bulunmaktadır. 17 görselin bulunduğu "Sofra Düzenleri ve Servis" bölümü (s. 37-66), kitapta en fazla görselin bulunduğu bölümdür. Bu bölümde masa düzenleri ve oturma planları ile ilgili ayrıntılı görsellerin bulunması, yazarın konuyu somutlaştırarak hedef kitlesini özellikle bu konuda eğitmeye 
çalıştı̆̆ının da göstergesidir. Bölüm içlerinde yer alan görseller, yemeklerin siyah beyaz fotoğrafları (kış salatası, biber dolması, su böreği vs) ve mutfak, mutfak ekipmanı ve masa düzenlerinin anlatıldığı çizimlerden ve fotoğraflardan oluşmaktadır. Özellikle yemek fotoğraflarının siyah beyaz olması, yemeğin görüntüsü ve tabaktaki sunumunun net şekilde görülmesine engel olmaktadır. 22 bölümden oluşan kitapta kahvaltı, yemekler, tatlılar ve yiyeceklerin saklanmasını içeren 20 bölüm için ayrı kapak sayfaları hazırlanmış beslenme hakkında bilgi verilen ilk bölüm için kapak hazırlanmamıştır. Bölüm kapak sayfalarında bölüm başlı̆̆ı ile hazır grafikler ve çizimler kullanılmıştır. Kitapta insan görseline "Hamur İşleri" bölümü sayfalarında ve üç bölümün kapak sayfasında rastlanmaktadır. "Sofra Düzenleri ve Servis" Bölümünün kapak sayfasında yer alan hazır görselde, restoran masasına oturmuş ve elindeki kadehi yukarı kaldıran takım elbise giymiş bir erkek kullanılmıştır (s. 37). "Yumurtalar" bölümünün kapak sayfasında (s. 123) ve yine "Hamur İşleri” bölümünde su böreğinin hazırlanışı ve "Şuale Krem Büsküvi”" tarifinde profesyonel aşçı gömleği giyinmiş bir erkeğin eli, hazırlık yaparken görünmektedir (s. 303, 309). "Hamur İşleri”, "Süt ve Sütten Yapılan Tatlılar” Bölümünün kapak sayfalarında yer alan kadınlar, domestik mutfakta, erkek ve kız çocukla beraber çizilmiştir. Bu görsellerin dışında özellikle "Hamur İşleri” bölümünde yine domestik mutfakta önlügüüle yemek hazırlayan kadınların ellerinin fotoğrafları vardır. Kitapta kullanılan bu görseller, mutfakta erkeği profesyonel, kadını ise amatör olarak kodlamaktadır. Kadın, önlüğü ile evinin mutfağında, kimi zaman çocuklarıyla, ailesine yemek hazırlarken erkek ise giydiği ve kendisine bir statü veren aşçı üniformasılyla (aşç1 gömleği) temsil edilmektedir. Bu görsellerdeki kadın ve erkek temsilleri, araştırmacı ve okurlara dönemin toplumsal cinsiyet rolleri hakkında ipucu vermektedir.

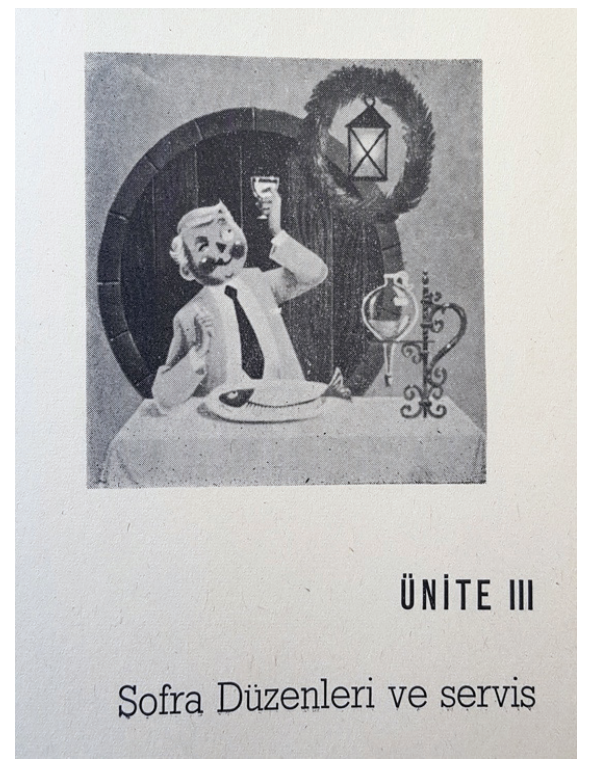

Görsel 3. Kitapta yer alan Sofra Düzenleri ve Servis Bölümü’nün bölüm kapağı. 


\section{Kitabın Hedefi ve Hedef Kitlesi}

Kitabın yazarı ve özellikle giriş bölümünde belirlediği hedef kitlesi, Wheaton'ın da belirttiği gibi o toplumdaki toplumsal cinsiyet ve sinıf hakkında bilgi verir (Wheaton, 2009, s. 11). Kitabın önsöz bölümünde beslenme kurallarına uygun yemek pişirmenin ev kadını için çok önemli olduğunu belirten Cılızoğlu, kitabı ev kadınlarına ve öğrencilere yardım amaçlı, beslenme bilgileri ve bu bilgilere dayalı yemek pişirme metod ve uygulamalarını birlikte veren bir kitabın eksikliğini gidermek için hazırladığını ifade eder (s. VII). İyi ve dengeli beslenmenin tüm dünyada sorun olduğuna dair saptamayla başlayan yazar, beslenmenin tanımına, önemine, öğelerine, dengeli beslenmenin ilkelerine, besin maddesinin vücut için önemine, satın alınmasına, saklanmasına ve pişirilmesine dair bilgi eksikleri olduğunu düşünerek bir eğitim ve yardımcı olarak hazırlamıştır kitabı. Giriş bölümünde yazar, kadınları, tüm dünyada olduğu gibi ülkemizde de yaşanan yetersiz ve yanlış beslenme sorununun üstesinden gelecek uzmanlar olarak gördüğünü ve ilgili konular hakkında "bir ev kadınına yetecek" kadar bilgi verdiğini belirtir. Kitabın hedef kitlesi, Cumhuriyet ideallerini yaşatacak bireyleri, sağlıklı ve dengeli şekilde besleyecek eşler ve annelerdir. Bu eşlerin ve annelerin artık Batılı kadınlar gibi ev ve aile hayatına dair her konuda bilgili olmaları gerekir. Yenal'ın belirttiği gibi kadının rolünün, Batı normlarına benzetilerek yeniden yapılandırılmasıyla modernleşme projesinin bir parçası olarak ev hayatının yeni ideallerinin, biçimlerinin ve normlarının geliştirilmesi kolaylaşır. Kız Enstitüleri ve diğer eğitim kurumlarının özellikle yemek ve pişirme dünyasına ait modern kategorilerin devlet tarafından nasıl tanımladığını, yapılandırdığını ve teşvik ettiğini göstermeye çalışan Yenal, sağlık ve hijyen vurgusunun 1950 'lerin mutfakta modernleşmeyi ${ }^{10}$ sembolize ettiğini ifade eder (2007, s. 191-192). C1lızoğlu'nun çalışması da 1970'lerde yazılan bir çalışma olarak sağlıklı ve dengeli beslenme kadar hijyen konusuna özellikle yiyeceklerin saklanması, evde ve mutfakta temizlik konularıyla dikkat çeker. Eğitimli ideal Cumhuriyet kadınlarının sağlıklı ve dengeli beslenme kadar yiyeceklerin nasıl takdim edileceği bilgisine de sahip olmaları gerekir. Bu nedenle, kitapta pişen yemeğin takdimi, sofranın düzenlenmesi, sofranın görgü kuralları ve kokteyl hazırlanması hakkında bilgiler de verilir (s. VII). Kitap, bir yandan okullarda eğitim gören kadın öğrencilere diğer yandan da bu okullara gidememiş ve bu okullardan bilgi alamayan ama okuma-yazma becerisine sahip kadınlara yönelik hazırlanmıştır.

Kitabında yemekle sağlıklı, güçlü ve mutlu bir toplum arasında bir ilişki kuran Cılızoğlu, bedenen ve ruhen sağlıklı olan kişilerin, iyi ve düzenli çalışma gücüne sahip insanlar olarak, "me’sut insan ilişkileri ile ekonomik ve sosyal bağları kuvvetli toplumu meydana getirdiğini” belirtir (s. 2). Sağlıklı bireylerin, güçlü bir toplumun önkoşulu olarak işaret edildiği bu yaklaşımda tüm sorumluluk kadınlarda ve onların eğitimlerindedir.

10 Yenal, 1930 ve 1940'larda mutfakta modernleşmenin, "Avrupalı" yemekler anlamına geldiğini ifade eder. 1950’lerde Amerikan hegemonyası bağlamında modernleşme sürecinin hızlandığı ve bu süreçte Kız Enstitüleri'nde yemek pişirme derslerinde bilimsel beslenmeye geçildiği, besin ve besin değerlerinin önemine vurgu yapılması söz konusudur (2007, s. 198, 200). 
$\mathrm{Bu}$ eğitimin merkezinde bulunan Kız Enstitüleri, Öğretmen Okulları ve Akşam Sanat Okulları, modernleşme projesinde kadınların eğitiminde merkezi bir rol oynamaktadır. Bu kurumlarda verilen eğitimin amacı, domestik yaşamın her yönü hakkında bilgi sahibi olan, evini ve ailesini uygar ve modern tarzda çekip çevirecek, onlara sevgiyle ve itinayla yaklaşacak "ideal kadın"1 yetiştirmektir (Yenal, 2007, s. 198). Ev ekonomisi ve yönetimi, dikiş, yapay çiçek yapımı, resim, yemek pişirme ve çocuk bakımı gibi konularda eğitim veren bu eğitim kurumları, hem verdikleri dersler hem de yayınları ile hedeflenen toplum idealine ulaşmak için öğrencilerini ve halkı eğitmektedir.

Kitapta hedef kitle, ev kadınları ve öğrenciler olarak belirlenmiş olmakla birlikte tariflere, araç-gereç dökümü yapılan mutfaklara, tarif edilen ziyafet sofralarına ve uyulması beklenen görgü kurallarına bakılınca hedef kitle ile ilgili bir belirsizlik hatta karışıklık olduğu düşünülebilir. Kitapta yer alan tariflere bakılırsa yazar, mercimek çorbası, zeytinyağlı fasulye, etli yaz türlüsü, sigara böreği, etli nohut gibi tariflerin volovon, kuşkonmaz, mayonezli böcek, karides pilakisi, mantarlı istiridye gibi yiyeceklerin ve white lady, cin fizz gibi içeceklerin aynı evlerde tüketilmesini beklemektedir. Kitabın, seslendiği hedef kitleyi değerlendirirken kullanılacak bir başka ipucu, kokteyl tipi masa tanziminin anlatıldığı "Sofra Düzenleri ve Servis” bölümündeki "Bu usülde içkiler ve yemekler tepsiler içinde hazırlanır. Garsonlar veya ev sahibine yardım eden kişiler tepsi içersisinde hazırlanmış yiyecek ve içecekleri ikram ederek misafirleri ağırlarlar, ..." ifadesidir (s. 51). Bu cümlede evinde kalabalık bir gruba davet verebilecek imkânlara sahip, yanında yardımcı veya bir davet için garson çalıştırabilecek bir gruptan bahsedilmektedir. Dolayısıyla kitabın "Giriş" bölümünde belirlenenden daha sınırlı bir gruba seslenildiği ya da farklı toplumsal kesimlere yönelik olarak hazırlandığını düşünmek yanlış olmaz. Bütün bu örneklerle beraber kitaptaki görgü kuralları da düşünülünce, hedef kitlenin belirlenmiş standartlar ve bu standartlara uygun yaşaması istenen ama henüz varolmayan, yaratılmak istenen hayali bir topluluk olduğu anlaşılır. Benzer şekilde Yenal da 1940 yılında yazılan bir yemek kitabının içindekiler bölümünde verilen başlıklara (açık büfe düzenleme ve akşam yemeği daveti menüsü) ve tariflerde verilen malzemelere (şinitzel, mayonezli balık, vs.) odaklanarak bunlara ulaşmanın dar gelirliler için mümkün olmadığını hatta o zaman için büyük bir kesimin bunları bilmediğini ifade eder. Bu tespitten yola çıkarak, 1940'larda Kız Enstitüleri'ndeki eğitimin teorik, elitist ve toplumsal olarak dışlayıcı olduğunun kanıtlandığını belirtir (Yenal, 2007, s. 198). Hem bu çalışmada incelenen kitap hem de Yenal'ın örneği, Ken Albala ve Barbara Wheaton'un yemek kitaplarının her zaman dönemin gerçek gündelik hayatını yansıtmayacağı argümanını doğrulamaktadır.

\section{Yemek Kitaplarında Gıda Güvenliği}

Yemek kitapları, beslenme ve tarifler hakkında bir kaynak olduğu kadar mutfakta güvenli şekilde yiyecek hazırlama ve saklama ile ilgili kurallara ve önerilere de yer 
verebilir. Bu konudaki bilgiler, süreç içinde gıda güvenliği, mutfakta öngörülen ve karşılaşılan kazalar ve bunlardaki değişimler hakkında bilgi verir. Scholliers' in çalışması (2008) yemek kitaplarında dönemin gıda güvenliği anlayışı hakkında bilgi edinilebileceğine değinir. Bir yemek kitabında, yemek pişirme için kullanılan yeni mutfak ekipmanlarının, sıcak ve soğuk depolama ve sıcaklık ölçüm araçlarının bulunmasının; temizlikteki gelişmenin görülmesinin (yeni temizlik ürünleri); besin kaynaklı hastalıklar hakkındaki bilginin artışının ve tüketici eğitim materyalinin bulunmasının gıda güvenliği hakkında bilgi sağlayacak kaynaklar olduğunu işaret eder (aktaran Almanza, 2017, s. 599). Cılızoğlu'nun kitabında gıda güvenliği ile ile ilgili bu ipuçlarına özellikle iki bölümde rastlanmaktadır. Bunlardan ilki "İnsanların Besin İhtiyacı ve Yemek Listeleri Düzenlemeleri Hakkında Bilgi” adlı 1. bölümde yer alan "Besin Zehirlenmeleri Hakkında Kısa Bilgi" başlığı (s. 16-19), ikincisi ise "Yiyecekleri Saklama ve Usulleri ve Kışlık Yiyecek Hazırlama Bölümü” dür (s. 423-489). Besin Zehirlenmeleri Hakkında Kısa Bilgi başlığ 1 altında zehirlenmelerin yiyeceklerden gelen bakteriler, yiyeceklerin pişirildiği kapların yapıldığı maddeler ve zehirli bitkiler ve hayvanlar aracıllğıyla yaşandığı ifade edilmektedir. Zehirlenmelere sebep olan bakterilerin ürememesi için yiyeceklerin soğuk yerlerde saklanması gerektiğine, soğuk yerlerin ya da buzdolaplarının olmadığı durumda tüketilecek kadar alınmasına ve hazırlarken temizlik kurallarına uyulmasına vurgu yapılmaktadır. Bu bilgi, buzdolabının dönem bağlamında henüz her mutfakta bulunmadığının işaretidir ${ }^{11}$. Nitekim ilerleyen sayfalarda yiyeceklerin saklanması ve dondurulmuş gıda tekenolojisi hakkında ifade edilenler bu bulguyu doğrulamaktadır. Kısa süreyle yiyecekleri "buzdolaplarında, soğuk bodrum ve kilerlerde saklamak gerekir" diyen C1lızoğlu, bu saklama yönteminde soğuğun yiyecekleri bozan mikro organizmaları uyuşturduğunu, faaliyetlerini durdurduğunu, mikro organizmaların üreyecek ortam bulamadığı için yiyecekleri bozmadığını ve yiyeceklerin hangi nedenlerle bozulduğunu okuyucularına bilimsel bir şekilde anlatır. Yiyecek saklama tekniklerinin anlatıldığı bu bölümde 1970'li yıllarda dondurulmuş gıda üretiminin yaygınlaşmadığı bilgisini verirken bunun nedenlerinden ilkini taşımacıllğın henüz yeterince gelişmemesi olarak işaret eder. Taşıma araçlarının azlığı ve bu araçlarda dondurulmuş gıdayı olduğu gibi muhafaza edecek teknolojinin bulunmamas1, ürünlerin \% 40 'a varan oranda ziyan olmasina neden olmaktadır. Dondurulmuş gıda teknolojisinin gelişmemesinin ikinci nedeni ise bu gıdaları buzu çözülmeden evlere ulaştıracak ve evde saklayabilecek teknolojinin bulunmamasıydı. $\mathrm{Bu}$ durum ise marketlerden alınan dondurulmuş gıdaları taşıyacak dondurulmuş gıda torbalarının üretilmesi, geçen elli yılda buzdolapları ve deepfreezelerin mutfakların olmazsa olmaz ürünü hale gelmesi ve teknolojisinin (sebzelerin nemini koruyan ve bir ay süreyle teze tutan, akıllı buzdolapları vb.) hızla gelişmesiyle sonuçlanmıştır. Benzer şekilde Sauner de taşımacılığın gelişmesi ile birlikte daha önce taze sebze ve meyveye ulaşma sıkıntısının çözüldüğünü belirtir (aktaran Samancı, 2019, s. 18).

11 Buzdolabı, Türkiye'de ilk kez 1930 yılında ithal bir ürün olarak kullanılmaya başlanmış, 1958 yılında Arçelik firması buzdolabı üretimine başlamıştır (Emiroğlu, 2011, s. 128). 
G1da güvenliği bağlamında önemli olan gıdayı saklama tekniklerinden biri de soğukta granülleştirmedir. Teknolojik yetersizlikten dolayı soğukta granülleştirme metodunun ülkede kullanılamadığını belirten Cılızoğlu'ndan toz meyve sularının o dönemde market raflarında olmadığını, dondurarak kurutma teknolojisinin henüz gelişmekte olduğunu ve konuyla ilgili araştırma yapan bir araştırma merkezi bulunduğu bilgisi edinilir (s. 433) $)^{12}$.

Kitapta kimyasal gıda zehirlenmelerine aliminyum, bakır, gümüş, çinko gibi kapların sebep olduğu ifade edilirken şu anda mutfaklarda kullanılan çelik, teflon gibi malzemelerin henüz mutfaklara girmediği ortaya çıkmaktadır. Meyve ve sebzeleri haşerelerden korumak için arsenikli ilaçlar kullanıldığı ama bugün kullanılan ilaç çeşitliliğine henüz bu dönemde rastlanmadığı, günümüzde gıda üretiminde kullanılan GDO’nun (genetiği değiştirilmiş organizma) literatüre girmediği, zehirli bitki olarak sadece mantara, insanları zehirleyecek bir hayvan olarak istiridye ve midyeye işaret edildiği ortaya çıkmaktadır.

\section{Yemek Kitaplarıyla Düzenlenen Ev, Mutfak ve Sofra}

Bir yemek kitabında kullanılan görseller, verilen kurallar ve öneriler, iş planları ve mutfak donanımı, dönemin gündelik hayatı ve buradaki ilişkileri yansıtabileceği gibi olması istenen ideal bir yaşamı oluşturmak için de kullanılıyor olabilir. Evin, mutfağın ve buna bağlı olarak aile ve toplumsal ilişikilerin nasıl olması gerektiğine dair kuralların belirlendiği, olanı değil de olması gerekenin işaret edildiği, toplumu idealleştirmeye yönelik bir çabanın ürünü olarak değerlendirilebilecek bu kitap, Tonnar'ın da ifade ettiği gibi sadece bir yemek kültürünü değil arzu edilen kültürel anlatılar oluşturmak için mutfağın ötesine uzanmaktadır (2008, s. 2). Bu bağlamda Cılızoğlu'nun kitabının ideal bir toplum oluşturma yolunda kurallar koyduğu ve hali hazırda yaşanan gündelik hayatı düzenlemeye çalıştığı çeşitli örnekler üzerinden anlaşılabilir. Örneğin, kitapta mutfak hakkında bilgilerin verildiği "Mutfak Hakkında Bilgi” adlı 2. Bölüm (s. 21-36), iyi bir mutfağın özelliklerini ve mutfak planlarını, mutfak araç ve gereçlerini, mutfağın nasıl temizleneceğini, mutfakta emniyetin nasıl sağlanacağını ve bulaşıkların nasıl yıkanacağını detaylı olarak anlatır. Bu bölümdeki bilgiler, kadınların yapması gereken günlük, haftalık ve mevsimlik işler listesinin dökümünü yapmaya olanak vererek kadınların gündelik ve ev hayatlarını yapacakları iş üzerinden planlar. Cumhuriyetin ilk yıllarından itibaren hep daha fazlası beklenen Türk kadınının kamusal alanda ulusu ve eşini temsil ederken ev kadınlığı rolünü de yerine getirmesi beklenir. C1lızoğlu bu düşünceye uygun olarak kitabında, evinin tüm işleriyle bizzat ilgilenen bu kadınların ne zaman elektrik lambalarının tozunu alacağını, perdelerini silkeceğini, buzdolabının buzlarını eriteceğini, erzak kontrolü ve boya badana yapacağını onlara öğretir ve planlar. Bu bilgiler kullanılarak kitabın hedef kitlesindeki grubun, gündelik zamanı

12 Bursa Konservecilik Araştırma Enstitüsü, 1961 yılında konserve, salça, meve suyu sanayileri ve bu sanayilerin makine ve ambalaj kuruluşlarının gelişimine ve kalitelerinin arttırılmasına yönelik çalışmalar yapmak amacıyla kurulmuştur. 
nasıl kullandığı veya kullanması gerektiği ve rutinleri hakkında bilgi edinmek mümkündür. $\mathrm{Bu}$ iş listeleri ile yapılan planlamanın esası, enerji ve zaman kaybının önüne geçerek kadının görevlerini yerine getirmesini ve tüm hayatı verimlilik esasına göre düzenlemesini sağlamaktır.

Yemek kitaplarının yazıldığı dönemin gündelik hayatı ve insanlarının rutin yaşamlarını yansıtmanın ötesine geçerek birtakım kurallarla, mahrem alanı düzenlemeye çalı̧̧masına bir başka örnek, kitaptaki "Sofra Düzenleri ve Servis" bölümüdür (s. 3666). Cılızoğlu'nun kitabının yemek pişirme yanında, başlığında da belirtildiği gibi bir yemek görgü kitabı olması, hedef kitlesi olan ev kadınlarına aynı zamanda adab-1 muaşereti öğretmeye çalıştığının kanıtıdır. Batılılaşmanın hedef olarak gösterildiği erken Cumhuriyet döneminde mimari bir hareketle önce bir "görsel modernlik kültürü" oluşturulmaya çalışıldığını ifade eden Bozdoğan'a (2015) atıfla bu yemek kitabının da varolanları değiştirmeye ve yeni bir kültür oluşturmaya çalıştı̆̆ını söylemek mümkündür. Elbette yemek kitaplarında batı mutfağının etkilerinin görülmesi yeni bir durum değildir. 19. yüzyılın ikinci yarısı itibariyle alafranga yemek tarzı ve sofra kuralları Osmanlı elitleri arasında moda olmuştur. Bu dönemde Avrupa tarzı masa düzenleri, masada yemek, sandalyede oturmak, bireysel bıçak, çatıl, kaşık, bardak kullanımı ve Avrupa porseleni gibi sofra takımları kullanılmaya başlanmıştır. 19. yüzyılın sonuna doğru 3 ögün yemek kuralı bir kent kültürü kuralı haline gelmiştir. Fransız ve Avrupa mutfağının Osmanlı mutfağının yemeklerini ve servis düzenini etkilemeye başladığı bu dönemde hazırlanan yemek kitaplarında aynı zamanda Fransa ve Avrupa mutfağından tarifler krema, pasta, bisküvi, kalıp dondurmalar yer almaya başlamıştır (Samancı, 2019, s. 17). Ancak bu dönemde batının mutfak kültürü üzerindeki etkisi, İstanbul elitlerinin mutfağı üzerinde gerçekleşmektedir. Batının mutfak ve yemek kültürünün genele yaygınlaşması için çabalar, Cumhuriyetin yeni bir ulusu yaratma amacıyla başlar. Cılızoğlu'nun çalışması da bu amaçla ilişkili olarak yeni ve modern bir ulusu yaratmak için, tüm ulusun modernleştirilmesi gerektiğini öneren düşüncenin ürünü olan eğitim kitaplarından biridir.

Modern ulusun yaratımında özel alanın dönüşümünün zorunlu olması ve bu dönüşümde eğitimli kadının gerekliliğinin sonucu olarak ortaya çıkan eğitim kurumları, önce kadınlara onlar aracılığıyla da tüm ulusa batının bilgi ve görgüsünü öğretmeye çalışmaktadır. Ne yendiğinin ve yeme davranışlarının kimliğin bileşenleri hakkında bir anlam aktardığı düşünüldüğünde hazırlanan yemek masası, masadaki yemekler ve masada bulunanların davranışları oldukça önemli hale gelir. Eski alışkanlık ve davranışların yerine yenisini öğretme ve yerleştirme çabasında "Eti keserken kendinize en yakın olan parçaya çatalınızı batırınız, ... bıçakla bütün et kesilip parçalar tabakta bırakılmaz, ancak yenilcek miktar kadar kesip yemek lazımdır" ya da "yemeğin suyuna ekmek banılmaz, çatala ekmek takılır ve sonra suya batırılır" gibi ifadeler, hedef kitleye yemeğin nasıl yenmesi gerektiğine dair bir eğitim ve bilgi verir. Bu kitabı okuyan 
yabancılar için ise kitap, hazırlandığı coğrafyanın insanlarının kimler olduğuna dair yaratılmak istenen imajı iletmenin aracıdır.

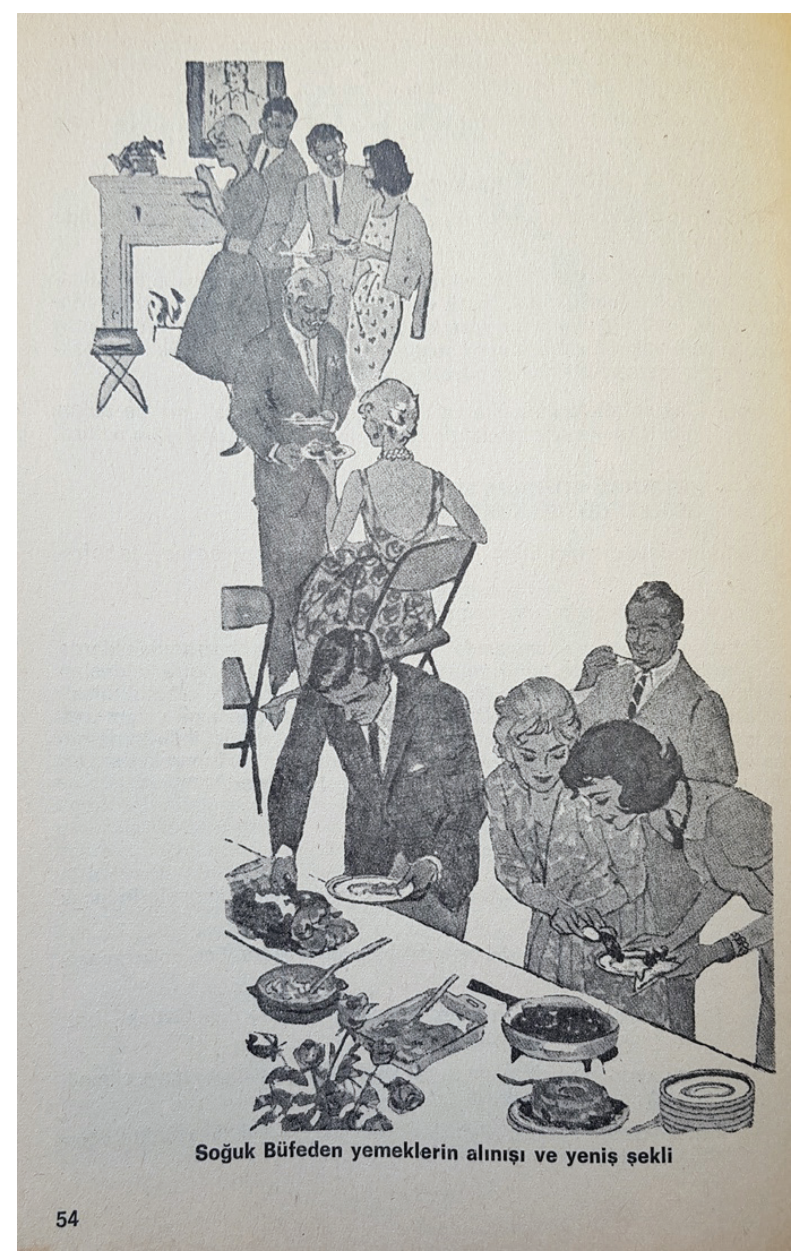

Görsel 4. Kitapta, adab-1 muaşeret üzerinde özellikle durulan konulardan biridir.

Kitapta ziyafet sofraları ve burada uyulması gereken kuralların anlatıldı ̆̆ sayfalar, yaratılmak istenen toplumun ailesini ve onun üzerinden dönemin modernlik anlayışının ne olduğunu gösterir niteliktedir. Ziyafet sofralarına, yeni dostlukları geliştirmenin ve güzel bir gün geçirmenin aracı olarak işaret edilirken bu sofralarda kullanılacak kadehler, tabaklar, sunulacak yemekler, davetlilerin yapması gerekenler, yemeklerin servis sırası gibi pek çok konudan bahsedilir. Ziyafet sofrasında "grepfruit", karpuz, muz, portakal, mandalina gibi "yenmesi zor meyvaların" çatal bıçak kullanılarak nasıl yeneceği, midye ve istiridyenin çatalla ve bir lokma ekmekle nasıl yeneceği (s. 57), 
ziyafet sofralarında tatlı ve meyvalarla servis yapılan tatlı şaraplar, yemeklerle servis yapılan "Sek" tatlı olmayan şarapların tasnifi ve hangi bardakla ya da kadehle içkinin nasıl servis edileceği büyük bir incelikle anlatılır. Kitapta verilen çizimlerde ve anlatılan ziyafet masasındaki oturma düzeninde misafir kadın, ev sahibi erkekle misafir erkek, ev sahibi kadınla yan yana oturtulmaktadır (s. 48). Öğretilmeye çalışılan bu davranış kodlarının ve görgü kurallarının gerçek gündelik hayatta bulduğu karşılığın ne olduğunu kestirmek için, bir ziyafet sofrasının hem maliyetini karşılayabilen hem de “gerekliliklerini” yerine getirenlerin 70'ler Türkiyesi’nde kimler olduğunu düşünmek yeterlidir. Yenal, Kız Enstitüleri'nin yeni bir burjuva domestik alanının yaratımına katkı sağladığını ve kadın aracılığıyla gerçekleştirilen bu yapılanmanın (1989, s. 105, 2007, s. 192) tüketim ilişkileri bağlamında sınıfin, statü ve toplumsal cinsiyet kodlarının doğuşunda önemli etkileri olduğunu belirtir. Devletin eğitim kurumlarıyla teşvik edilen ev ve aile yaşamının yeni normlarının, orta sınıfın konumunu ve kültürel beğenilerinin önemli bir göstergesi olduğunu belirten Yenal, çalışmasında bir milli eğitim bürokratının modernleşme için yapılanlara Türk toplumunun uyum sağlamakta zorlandığ 1 ve doğunun toplumsal normlarından özgürleşilemediğini belirten sözlerini alıntılar (2007, s. 204). Yenal'ın aktardıklarından hareketle Cılızoğlu'nun kitabının içeriğinin de ideal bir toplum tahayyülünün uzantısı olarak oluşturulduğunu söylemek kolaylaşır.

Kitapta verilen bilgilerin ve anlatılan görgü kurallarının anlatım tarzı, C1lızoğlu'nun aldığ 1 formasyonun, eğitim ve gündelik hayatı planlama ve bir düzene koyma konusundaki çabanın sonucu olarak, emir verir nitelikte ve kuralcıdır. Örneğin "Ziyafet Sofrasında Dikkat Edilecek Hususlar” (s. 53-56) bölümünde masada otururken yapılacaklar ve yapılmayacaklar, nasıl oturulacağı, nasıl yemek yenileceği maddelenerek anlatılır. "Peçete, tabak altına konulmaz, yakaya takılmaz, dizler üzerine alınmalıdır... Şampanya içilen bir yerde şampanya patlatmak ayıptır. ... Konuşurken sözlerimizin önemini belirtmek üzere, öne doğru abanmamalıdır.” gibi örnekler, kitapta mutfak çerçevesinde konulan kurallarla gündelik hayata düzen verilmeye çalışıldığının bir başka kanıtıdır. Kuralcı ve emir kipiyle konuşan kitap, rasyonalizm tarafından düzenlenen, batının özel alanının kurallarını bu coğrafyaya ikâme ederek toplumun gündelik hayatını örgütleme-düzenleme çalışmasının ürünü ve siyasal iktidarın gündelik hayatı örgütleme ve planlama misyonunun özel alana nüfus etmesinin oldukça "masum" ideolojik bir aracı haline gelir.

\section{İdeal Bir Mutfak}

Mutfak araç gereçleri ve pişirme tekniklerini yemek kitapları incelemesinde bir başlık olarak kullanmak, yiyeceklerin hazırlanması sırasında kullanılan araç gereçlerin dökümünü yapmak, yiyeceğin kaynağından bahsetmek, pişirme aletlerini ve yöntemlerini toplamak, saklama tekniklerinden bahsetmek mutfağın kendisi, düzenlenmesi ve mobilyaları hakkında bilgi verir ve böylece mutfağın niteliği ortaya 
çıartılabilir (Wheaton, s. 6, Albala, s. 117). C1lızoğlu'nun bir eğitim materyali olarak hazırladığı kitabında ise dönemin mutfağı ile ilgili bilgilere hem 2. Bölümden (s. 1937) hem de tariflerin ve yiyecek saklama ile bilgilerinin verildiği 22. Bölümden (s. 423-489) ulaşılır. L, U, I şeklindeki mutfak tiplerinin fotoğraflarla anlatıldığg "Mutfak Hakkında Bilgi” adlı 2. Bölüm. Cilızoğlu, mutfağın boyutlarını, boya tipini ve bunun buharlaşma ile ilişkisini, mutfakta sabit araçları (tezgâh, buzdolabı ya da tel dolap, lavabo, soba, kuzine, gaz ocağ 1 , havagazı gibi yemek pişirme araçları) ve sabit olmayan yemek hazırlama araçlarını tanıtır. Mutfak araç gereçlerinin dökümünü yapmak, farklı zamanlarda aynı işi yapmak için kullanılan araç-gereci tespit etmeyi, zaman içinde bu araçlardaki değişimi takip etmeyi, tasarımdaki dönüşümü ve malzeme zenginliğini anlamayı kolaylaştırır. 1971 yılına ait bu kitapta bir mutfakta bulunması gereken sabit olmayan araçlar olarak kaşık, bıçak, çatal, yumurta çırpma teli, püre makinesi, et makinesi, mikser, oyacak, kutu açacakları, çeşitli boylarda tencere-tava, ölçü kapları, bakır tepsiler sıralanmaktadır. Bunların yanında tarifler incelendiğinde "pyrex"13 cam kaplar, volovon ${ }^{14}$ hazırlamak için nemse ${ }^{15}$ kalıbı, manometreli tencere ve şişe kapatma aracı gibi yeni araç gereçlerle karşılaşılmaktadır. Metal, beton, fayans çalışma masaları (tezgah), buzdolabı veya tel dolap, lavabo, soba, kuzine, havagazı, gazocağı gibi pişirme araçları mutfağın sabit araçları olarak ifade edilir. Mutfaktaki bu araç-gereç dökümü ve "Balıklar" ünitesinde balıkların buzdolabında ya da evin en soğuk odasında dışarıdan temin edilecek buz kalıpları ile saklanması gerektiği bilgisi birleşince buzdolaplarının mutfaklarda 1970'li yıllarda henüz yaygınlaşmadığı bilgisi doğrulanır.

Kitapta Yiyecekleri Saklama Usulleri ve Kışlık Yiyecek Hazırlama adlı 22. Bölümde, daha önce bahsedilemeyen ve bugün mutfaklarda pek karşılaşılmayan bazı araç-gerece rastlanmaktadır. Örneğin, sebze konservesi yapmak için mutlaka manometreli tencereler, konserve yaparken tencerenin dibine kavanozlar çatlamasın diye konulan 1zgaralar birer ihtiyaçtır. Konserve yapmak için farklı kavanoz tipleri, "adi tencere”ler, bugün cilt bakımında kullanılan ve bazı meyve ve sebzelerde doğal olarak bulunan o dönemin evlerinde ise yiyeceklerin saklanması için kullanılan salisilik asit sıradan ekipman ve malzemeler olarak kitapta yer almaktadır.

13 Isıya dayanıklı cam kap, 1970’li yılların sonuna kadar yurtdışından ithal edilmektedir ve Paşabahçe tarafından yerli ısıya dayanaklı cam kapların adı haline gelen "Borcam" markası bu dönemde henüz geliştirilmemiştir.

14 Şu anda volovan olarak kullanılan bu kelime, milföy hamurunun ortası delik daireler şeklinde kesilip üstüste dizilmesi ve fırında içi boş şekilde pişirilmesi ile oluşan ve pişirildikten sonra iç malzeme ile doldurulup tekrar pişirilen bir hamur işinin adıdır.

15 Bir tür hamur kesme kalıbı. 


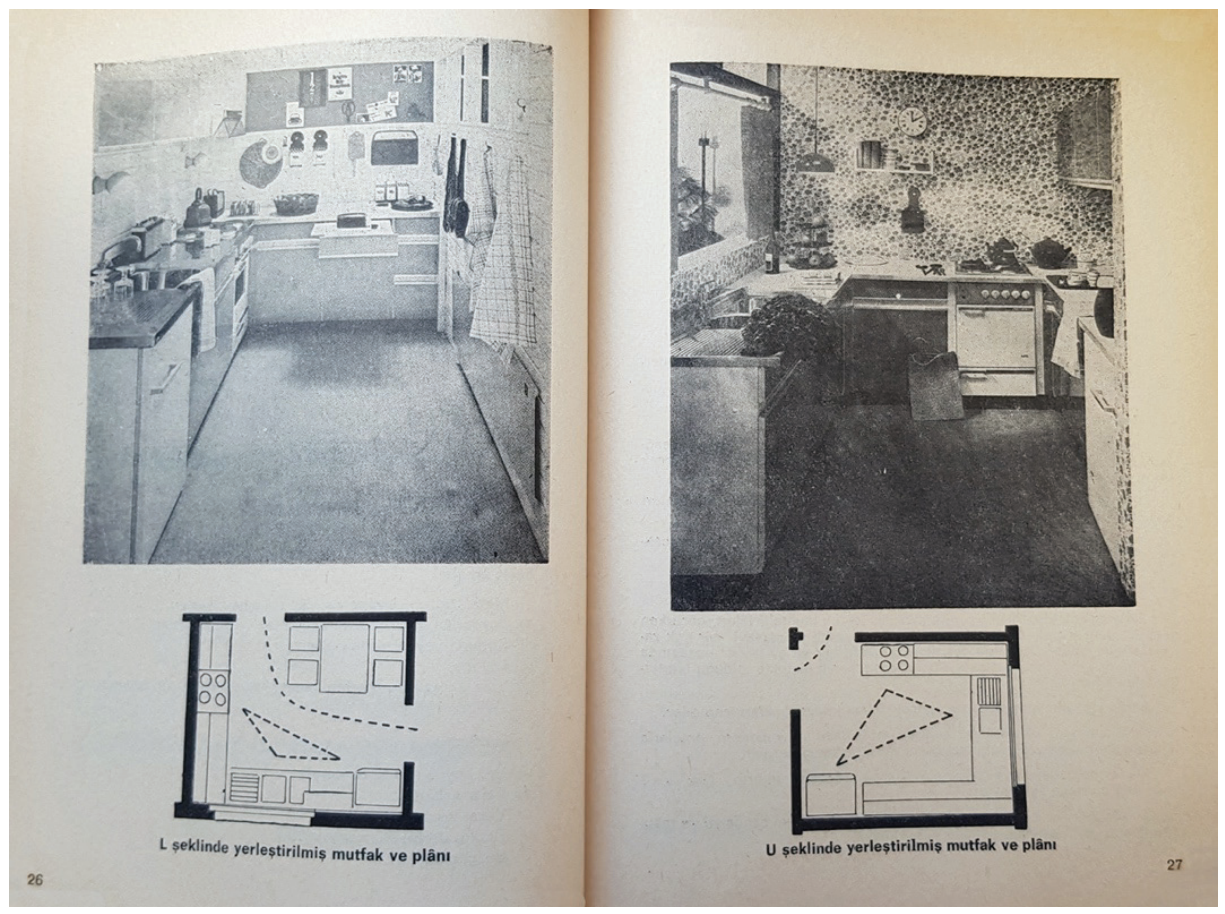

Görsel 5. Mutfak hakkında genel bilgiler verilen bölümde ideal bir mutfağın planları ayrıntılarıyla anlatılmaktadır.

\section{Bana Ne Yediğini Söyle: Tarifler}

Bir ülkenin beslenme rejimini yani halkının dönemsel olarak ne yediğini anlamak için yemek kitapları kullanışıı bir kaynak olabilir. Bu bağlamda bir yemek kitabında öncelikle "İçindekiler” bölümüne odaklanabilir. Yemek kitapları, ortaya çıktıkları dönemden beri belli şekilde örgütlenmiştir. İlk yemek kitabı olarak kabul edilen Apicius'un çalışmasında tarif isimleri, sayfada onları kolayca tanımlamak ve mümkün olduğu kadar tarif edilen yemek hakkında geniş bilgi vermek üzere verilir. Yüzyıllar geçtikçe yemek kitabının içindekiler bölümünde ilk düzenleme, servis sırasına göre, başlangıçlar, ara sıcaklar ve son yemek şeklinde yapılmıştır. Bu bölümleme, malzemelere göre de yapılmış 17. ve 18. yüzyılda yemekleri pişirme tekniklerine göre alt gruplara ayırarak içindekiler bölümü oluşturulmaya başlanmıştır (Willian, 2012, s. 7).

Bir yemek kitabının içindekiler listesi, yemeklerin isimleri ile şekillenebileceği gibi yemekleri pişirmek için kullanılan ana malzemeye göre de şekillenebilir. Kitabın içindekiler bölümünün listesini yapmak ve tablolar oluşturmak Albala'ya göre o mutfakta ve dönemde ne tür malzemelerin geçerli olduğunu, popüler olanların ya da o topraklarda olmayan malzemelerin neler olduğunu ortaya koyabilir (2013, s. 117). Benzer şekilde Wheaton da malzeme listesinin yerli ve yabancı gıdaları, en çok 
tüketilenleri ya da o dönemde olmayan gıdaları ortaya çıkartabileceğini belirtir (2014, s. 286). Cilızoğlu'nun yemek kitabının içindekiler bölümü, hem yemek türlerine hem de kullanılan malzemeye göre şekillenmştir. Örneğin, kitapta "Kahvaltı ve Önemi" başlığı altında kahvaltının önemi ve kahvaltıda tüketilebilecek yiyecekler anlatılırken ardından çorbalar, balıklar, kabuklu ve kabuksuz deniz ürünleri, yumurtalar, etler, et mamülleri ve sakatatlar, kümes hayvanları, salatalar, garnitür ve salçalar, yaş sebze kullanımları, baklagil ve tahıllar, hamur işleri, makarnalar, pilavlar, tatlılar, süt ve sütten yapılan tatlılar ve dondurmalar başlıkları altında 450'nin üzerinde tarif verilmektedir. Her bölümde, ilgili başlığın beslenmedeki yeri ve önemi, hazırlanırken ve pişirilirken nelere dikkat edileceği, tatlarının nasıl arttırılacağı, nasıl servis edileceği bilgisi verilmektedir.

Kitapta de en büyük hacme, 43 tarif ve 53 sayfa ile hamur işleri ve 54 tarif ve 42 sayfa ile yaş sebze kullanımları sahiptir. 31 tarif ve 21 sayfa ile etler ünitesi üçüncü sırada gelmektedir. Bu durum, o dönemde temel gida olarak unun ve tahılın önemli olduğu, tahıl ile yaş sebzenin gida tüketiminde ilk sırada yer aldığı ya da tüketimin bu şekilde gerçekleşmesi için bir yönlendirme yapıldığını düşündürtür. Yemek tariflerinin ana malzemesi bağlamındaki bu sayısal dağılım, elbette tüketim kadar üretim anlamında da yorumlar yapmaya izin verir. Nitekim kitabın içinde beslenme konusunun önemine değinirken C1lızoğlu'nun verdiği bilgiler, kitapta bu bölümlerin neden büyük bir hacme sahip olduğunu anlamaya yardımcı olur. Cılızoğlu yetersiz ve dengesiz beslenmenin tüm dünya için büyük bir sorun olduğunun altını çizerken ülke insanının besin ihtiyacını karşılamasını ve iyi beslenmesini sağlayacak şeyin, pahalı gıdalar almak olmadığının altını çizer:

İyi bir beslenme pahalı besin maddelerini almak demek değildir. Vücudun besin ihtiyacını karşılayacak besin çeşitlerini biliyorsak pahalının yerine ucuz olanlarını seçerek pekala vasat bir gelirle doğru beslenmek mümkün olabilir. Örneğin, Barbunya balığı yerine Palamut balığı yemekle vücudun protein ihtiyacı en iyi şekilde karşılanmış olur (s 2). 


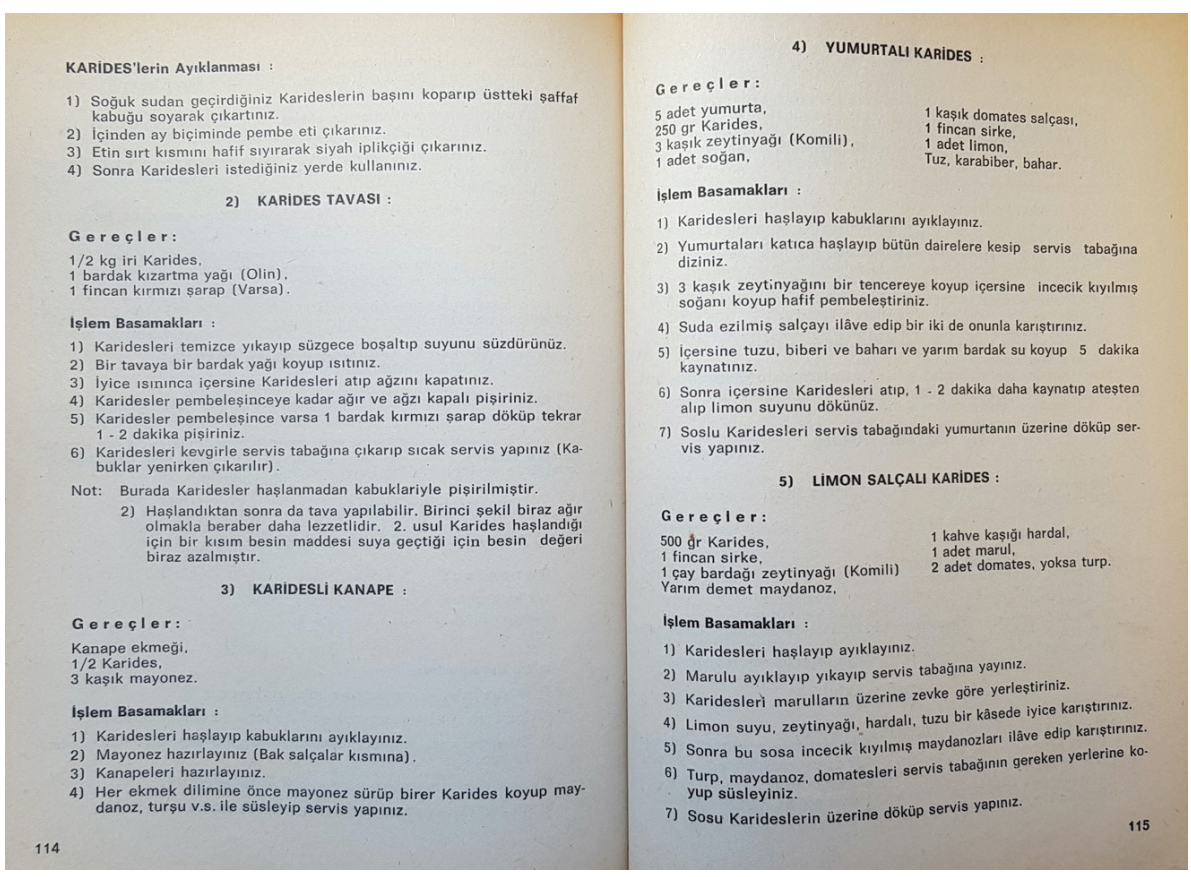

Görsel 6. Kabuklu ve Kabuksuz Deniz Ürünleri Bölümünden tarifler.

$\mathrm{Bu}$ ifade, ülkede bol yetişen ve ucuz olan tahıl ve sebzelere dair tariflerin kitapta daha çok yer tutmasını açıklayabilir. Cılızoğlu, ilerleyen sayfalarda yiyecekleri gruplara ayırarak birbirinin yerini tutan gidalarla, ucuz bir şekilde beslenmenin örneklerini vermeye devam eder (s. 2). Bu bilgilerle eldeki kıt kaynaklarla ulusu iyi beslemek, vatandaşlarına iyi bakmak devletin değil kadının görevi haline getirilir.

Yemek kitaplarının içinde yer alan tariflerin derlenerek mi yoksa yazar tarafından denenerek mi hazırlandığı bilgisi, yemek kitaplarının tasnifinde ve başarısının değerlendirilmesinde kullanılan önemli bir kriterdir. Driver "eğer bir roman, aklı veya hayal gücünü nasıl uyardığı ile ölçülüyorsa bir yemek kitabı da sadece tarifler yapıldığında, yemek tüketildiğinde ve tüm duyular kullanılarak analiz edildiğinde tam olarak anlaşılır. Pişirilmiş gıda, aslında basılı metnin bir ifadesidir" sözleriyle yemek kitaplarının başarı ölçütlerini sıralar (2015, s. 264). Değerli ve başarılı bir yemek kitabının belki de en önemli özelliği, tariflerdeki ölçü ve pişirme süresinin denenmiş ve başarılı sonuçlar doğrultusunda hazırlanmış olması ise Cılızoğlu'nun kitabı bu bağlamda başarılı bir kitaptır. Çünkü yazar, “Giriş” bölümünde kitapta örnek olarak verilen yemeklerin tümünün denendiğini ve olumlu sonuçlar alındıktan sonra kitaba geçirildiğini özellikle belirtmektedir. Kitapta yer alan tarifleri deneyenlerin görüşleri de kitabın başarısının değerlendirilmesinde önemli bir kriterdir. Bir başarı değerlendirmesi olarak kitap 
hakkında internette bulunan yorumlar incelendiğinde yazarın yemek pişirme beceri ve bilgisi olmayanlara bile "mükemmel yemek pişirteceği", kitabın her tür tarifi mükemmel şekilde anlattığı ifade edilmektedir ${ }^{16}$. Ancak kitapta tariflerin kaynağı, kimden öğrenildiği, nereye ait olduğuna dair hiçbir bilgi bulunmamaktadır. Albala (s. 118) tariflerin, yemeğin kaç kişi için yapıldığı ve nasıl bir hazırlık sürecinin bulunduğu, tarifin kimler tarafından kim için hazırlandığının anlaşılmasına yardımcı olacağını belirtir. Bu bağlamda giriş bölümünde tariflerin 6-8 kişi için olduğu bilgisi, dönemin kentli ailesinin yapısı ve büyüklüğü ile ilgili ipuçları verebilir. Kitaptaki tariflerin anne, baba ve çocuklardan oluşan 4 kişilik çekirdek aileye değil de aile büyükleriyle birlikte yaşanan geniş aileye referans verdiğini düşünmek mümkündür.

Yemek kitapları, yemeğin içindeki ana malzemeyi, malzemelerin ölçülerini, hangi sırayla ne zaman kullanılacaklarını okuyucularına anlatan-öğreten tariflerin biraraya gelerek mutfağın gıda ile ilgili kullanma kılavuzları olarak değerlendirilebilir. $\mathrm{Bu}$ tariflerdeki malzeme listesi, o dönemin mutfağında kullanılan sebze, meyve, et ve et ürünleri, baharat dökümü yapmaya da izin verir. Böylece bir malzemenin tarihsel olarak izini sürmek, bir coğrafyaya ne zaman girdiğini bulmak mümkün olabilir. İncelenen kitapta bu türden bir döküm yapıldığında örneğin baharatlara neredeyse hiç yer verilmediği ortaya çıkar. Yemek tariflerinde kullanılan baharatlar, tuz, karabiber, nane ve birkaç tarifte kullanılan kimyondan öteye geçmemektedir. Baharatla saklanan yiyecekler kısmında yapılışı anlatılan sucuğun tarifinde bile sadece karabiber, tuz, yeni bahar ve kırmızı biber kullanılmakta, zeytinyağlı dolmaların malzemeleri içinde kuş üzümünden ve fistıktan sonra "tuz, maydanoz, nane, dereotu ve baharatlar" şeklinde genelleştirme yapılmaktadır. Bugün pek çok mutfakta bulunan ve kullanılan kekik, isot, pul biber ve sumak gibi bulunması kolay baharatların isimlerine ise kitapta rastlanmamaktadır.

Kitabın içinde bulunan sebze listesinde patates, taze fasulye, bezelye, kabak, karnabahar, havuç, 1spanak, domates biber, salatalık, patlıcan, lahana, biber, pancar, enginar, kereviz, pırasa, barbunya, bakla, bamya yer almaktadır. Elma, portakal, limon, vişne, çilek, nar, şeftali, böğürtlen, üryani eriği (Kastamonu'da yetişen bir erik türü), kayıs1, "grepfruit", ayva ve mandalina o dönemde kullanılan ve tüketilen meyva çeşitliliğini göstermektedir. Kuru fasulye, nohut, börülce, yeşil mercimek, barbunya, pirinç, bulgur, kırmızı mercimek gibi malzemeler çorba, baklagiller ve tahıllar grubundaki yemek tariflerinde yer alan malzemelerdir. Hem sebze ve meyva hem de baklagiller listesine bakılınca yerli ürünlerin tariflerde kendisine yer bulduğu ancak yerel mutfaklarda kullanılan ya da ulusal sınırların dışından gelen ürünlerin isimlerinin olmadığı görülür. Bir sebze olarak patatesin beslenmede önemli olduğu özellikle garnitürler bölümünde verilen on dört çeşit patates tarifiyle ortaya çıkmaktadır. 
Yemeklere lezzet katan temel malzemelerden biri olan yağ, incelenen kitapta Sana yağı (Sanayağı), sade yağ, tereyağ, zeytinyağ ve kızartma yağı olarak kendine yer bulmaktadır. Burada dikkat çekici olan kızartma yağı ibaresinin bulunduğu yerlerde kimi zaman parantez içinde kimi zaman parantez kullanmadan bir marka olarak Olin, zeytinyağ yazıldığında ise Komili isimlerinin verilmesi (Cılızoğlu, s. 99, 101, 216) ve bir yağ türü olarak margarin ifadesinin yerine de bir markanın geçerek "Sana yağı" kelimesinin kullanılmasıdır. Yemeklerde kullanılan bu çeşitlilik daha önce tereyağı ve sade yağın yerini alacak yeni ürünlerin gelişmesine olanak verecek bir endüstrinin geliştiğini göstermektedir. Yağların dışında ayrıca bir çikolata markası olan Mabel de kitabın tatlllar bölümünde kendine yer bulur. Kitaptaki bu ifade biçimleri, şimdilerde bir pazarlama stratejisi olarak medya metinlerinin, gizli reklam ve ürün yerleştirme bağlamında kullanılmasını akla getirmektedir. Kitabın 1971 yılında yapılan ikinci baskısında ise bu türden gizli bir reklamın dışında daha önceki baskıda yer almayan, renkli basılmış ve katlanarak 256. ve 257. sayfaların arasına yerleştirilmiş Komili zetinyağının reklam broşürü bulunmaktadır. "Bu broşürün dışında kitabın son 3 sayfasında Hoover elektrikli aletleri, Turyağ markasının ürünü olan "Tursil”" sabun tozu, "UFA" margarin ve "Persil" yıkayıcı (toz çamaşır deterjanı) ve İş Bankası reklamlarına yer verilmiştir. Bu sayfadaki reklamlar da kitabın geri kalan kısmı gibi siyah beyaz şekilde basılmıştır. Kitapta yer alan bu reklamlar aracılığıyla kitabın basıldığı dönemdeki markalar ve ürünler kadar reklam sektörü hakkında da bilgi edinilmektedir.

Willian vd (2012), eskiden yazılan yemek kitaplarındaki tariflerin, genellikle birkaç satır olduğunu, ölçülerin yaklaşık verildiğini ve bundan başka detayın bulunmadığını şimdiki tariflerde ise kesin miktarların bulunduğunu, tüm aşamaların adım adım anlatıldığını ifade eder (s. 6). Cılızoğlu'nun ev kadınları için hazırladığı yemek kitabında da tarifler, tıpkı bir makinenin kurulum aşamalarını adım adım anlatan kullanım kılavuzunda olduğu gibi, bir yemeği hazırlamanın ve pişirmenin tüm aşamalarını maddeleyerek verir. Tarifler, malzemelerin verildiği “Gereçler” ve hazırlık ve pişirme sürecinin anlatıldığı "İşlem Basamakları" olarak iki bölümden oluşmaktadır. Tariflerin verildiği sayfalarda olmasa da daha önce değinildiği gibi yemeklerin 6-8 kişi için yapıldığı bilgisi Giriş bölümünde verilmiştir. Tariflerde kullanılacak malzemenin ölçüsü, gram, bardak ve kaşık olarak verilmektedir. Kitapta verilen tariflerde yemeği hazırlamanın ve pişirmenin süresine dair herhangi bir bilgi bulunmamaktadır. Kitapta, kadının evde yapacağı tüm işlerin planlandığı ve içinde yaşadığımız dönemde pişirilecek yemeğe hazırlanma süresi üzerinden karar verildiği bilgisi ile değerlendirildiğinde tariflerde bu ayrıntının bulunmaması ilginçtir.

\section{Sonuç}

İçinde yer alan bilgiler düşünüldüğüne yemek kitaplarının mekân olarak mutfağı, beslenmek için yiyecekleri, yemek hazırlamak için kullanılan araç-gereci, yemek 
ritüellerindeki davranışları ve kuralları düzenleme ve doğru kullanma kılavuzu olduğunu söylemek yanlış olmaz. Ciltleri, baskıları, boyutları ve içindekiler bölümünün genişliği ile mutfaklarda kendilerine yer açan yemek kitapları, mutfakta nelerin, nasıl doğru şekilde biraraya getirileceğine ve hangi amaçla kullanılacağına ve nasıl en iyi sonuç elde edileceğine dair bir başvuru kitabıdır. Bu başvuru kitapları neyi aradığını bilen bir araştırmacının elinde kitabın hazırlandığı dönemde ve coğrafyada bulunan yiyecek ve içecekler, yemek malzemeleri, pişirilen yemekler, yemeğin pişirilme yöntemleri, yemeği kimin kimler için pişirdiği, toplumsal cinsiyet rolleri, aile yapısı, mutfak ekipmanı, yiyecek ve ekipman üretcileri ve markaları, ev ekonomisi-idaresi anlayışı ve bunların eğitim içindeki yeri, ülkenin gıda ve tarım politikaları hakkında ipuçları yakalamak, bilgilenmek, değişimlerin izini sürmek ve bütün bunlar üzerinden daha geniş bir toplumsal, kültürel ve ekonomik analiz yapmanın aracı haline gelebilir. Böylece yemek kitapları içinde bulunan tüm bu bilgilerle yazıldıkları dönemi, farklı kaynaklardan okumaya ve anlamaya yarayan araştırmacılar için alternatif bir kaynak haline gelir.

Bu makalede incelenmeye çalışılan Leman Cılızoğlu'nun kitabı, Cumhuriyetin ideal topluma ulaşma yolunda önemli görevler verdiği Kız Sanat Okulları ve Öğretmen Okullarının eğitim-öğretim formasyonuna uygun olarak yine bu okullarda görev alan bir öğretmen tarafından hazırlanmış bir eğitim kitabıdır. Rasyonel bir yaşamın planlanması ve gereklilikleri hakkında bilgi veren kitap, özel alanda kadını özellikle mutfak, beslenme, gıda güvenliği ve sofra adabı üzerinden eğitmeyi amaçlamaktadır. Kitap, hem hedef kitlesini ve amacını belirlerken hem de kullandığı görsellerle cinsiyete dayalı iş bölümünde yemek pişirme, mutfağı düzenleme ve ev hayatını organize etme işlerini kadının görevi olarak işaret etmektedir. Kitapta yer alan içeriğe bakıldığında, kitabın varolan bir toplum ve onun gündelik hayatından çok ulaşılması istenen ideal bir topluma ve onun gündelik hayatına işaret ettiği anlaşılmaktadır. Kitapta yer verilen tariflerin, kitabın hedef kitlesindeki kapsayıcılığ 1 yanıstmaması dikkat çekicidir. Tüm ev kadınlarını eğitmeyi amaçladığını ifade eden yazarın kitapta yer verdiği bazı tariflerin adları ve içinde yer alan malzemelerin, ancak kentli üst orta sınıf tarafindan bilinebileceği ve erişilebileceği türden olduğu ortaya çıkar. Benzer şekilde hakkında bilgi verilen davet sofraları ve buralarda uyulması gereken kuralların da yine aynı sınıfın yaşam tarzının bir parçası olduğu ortadadır. Kitabın içeriğindeki dönemin mutfak, yiyecek hazırlama ve saklama teknolojisine dair bilgiler, bu teknolojinin ne kadar yaygınlaştı̆̆ını da ortaya koyarken yine tariflerde verilen malzemelere ait marka adları, dönemin yiyecek-içecek ürünleri ve reklam sektörü buna bağlı olarak ülkenin genel ekonomik durumu hakkında bilgi vermektedir.

Yemek kitaplarının içinde makro tarihin aktörleri ve olayları yerine gündelik hayatın sıradan ve önemsiz olarak nitelendirilen mekânı olarak mutfak ve yine cinsiyete dayalı işbölümünde kadın işi olarak değersizleştirilen yemek pişirmeye ait bilgiler vardır. Ancak yemek kitapları tam da bu değersizleştirilen ve sıradanlaştırılan mekân, kişiler 
ve pratikler üzerinden iktidarın düşüncesini kolayca pekiştirebilir ve yaygınlaştırabilir. De Certau'ya atıfla yemek kitaplarının iktidarın ya da güçlünün, zayıfın karşısında kullandığı stratejik bir araç olduğunu söyleyebiliriz. Bu bağlamda yemek kitapları, Chen'in ifade ettiği özel alanı hedeflese de kamusal alanla da ilişkilidir ve özel alanla kamusal alan arasındaki ilişkiyi anlamak için kullanılabilir bir kaynaktır. Yapılan çalışmalar incelendiğinde yemek kitaplarının, tarihin belli bir döneminin tüm diğer büyük anlatıları ve kurumları gibi modernleşme, uluslaşma, toplumsal değişim gibi "büyük amaçlar" için devlet ve siyasal iktidarlar tarafından kullanıldığı görülmektedir. Bu bağlamda şimdi yapılması gereken içinde bulunduğumuz dönemde kimlerin, hangi amaçların, hangi söylemlerle yemek kitaplarının içine girdiğini bulmaktır.

Hakem Değerlendirmesi: Dış bağımsız.

Çıkar Çatışması: Yazar çıkar çatışması bildirmemiştir.

Finansal Destek: Yazar bu çalışma için finansal destek almadığını beyan etmiştir.

Peer-review: Externally peer-reviewed.

Conflict of Interest: The author declares no potential conflicts of interest with respect to the research, authorship, and/or publication of this article.

Grant Support: The author received no financial support for the research, authorship, and/or publication of this article.

\section{Kaynakça/References}

Acar Tek, N. \& Sürücüoğlu, M. S. (2014). Basılmış olan ilk Türk yemek kitabı “Melceü’t Tabbahin”. Gazi Türkiyat, 14, 225-229.

Albala, K. (Ed.) (2013). Culinary history. In Routledge international handbook of food studies. Routledge.

Almanza, B. A., Byrd, K. S., Behnke, C., Ma, J., \& Go., L. (2017). Cookbooks in U.S. history: How do they reflect food safety from 1896 to 2014. Appetite, 116, 599-609.

Appadurai, A. (1988). How to make a national cuisine: Cookbooks in contemprary India. Comparative Studies in Society and History, 30(1).

Avakian, A. V. (2005). Shish kebap Armenians? Food and the construction, and maintenance of ethnic and gender identities among Armenian American feminists. In A. V. Avakian \& B. Haber (Eds.), From Betty Crocker to feminist food studies (pp. 257-280). Unversity of Massachusestts Press.

Black, S. (2010). Recipe for cosmopolitanism. Frontiers: A Journal of Women Studies, 31(1).

Bower, A. L. (1997). Bound together: Recipes, lives, stories and readings. In. A. L. Bower (Ed.), Recipes for reading: Community, cookbooks, stories histories, Massachussets Press.

Bozdoğan, S. (2015). Modernizm ve ulus inşast. Metis.

Brownlie, D., Hewer, P., \& Horne, S. (2005). Culinary tourism: An exploratory reading of contemporary representations of cooking. Consumption, Markets and Culture, 8(1), 7-26. http://dx.doi. org/10.1080/10253860500068937

Burke, P. (2014). Fransız tarih devrimi annales okulu (M. Küçük, çev.). Doğu Batı Yayınları.

Chen, Y. (2014). Recreating the Chinese American home through cookbook writing. Social Research: An International Quarterly, 81(2), 489-500. 
Cılızoğlu Eryılmaz, L. (1971). Yemek pişirme temel metod ve uygulamaları beslenme yemek görgü kuralları (2. basım). Emel Matbaacilık.

Cooke, N. (2012). Canada's food history through cookbooks. In M. Koç, J. Sumner, \& A. Winson. (Eds.), Critical Perspectives in Food Studies. Oxford University Press.

Driver, E. (2015). Cookbooks as primary sources for writing history. Food, Culture and Society, $12(3), 257-274$.

Emiroğlu, K. (2001). Gündelik hayatımızın tarihi. Dost.

Epp, M. (2015). Eating across borders: Reading immigrant cookbooks. Historie Social/Social History, $48(6), 45-65$.

Eser, G., \& Orak, A. (2015). Cumhuriyet dönemi kadın eğitiminde bir atılım: Urfa Kız Enstitüsü. Uluslararası Sosyal Araştırmalar Dergisi, 8(41). http://www.sosyalarastirmalar.com/cilt8/sayi41 pdf/2tarih_siyaset_uluslararasiiliskiler/eser_gulsah_abdullahorak.pdf

Gold, C. (2006). Danish cookbooks: Domesticity and national identity, 1616-1901. University of Washington Press.

Goody, J. (2013). Yemek, mutfak, sinlf. PinhanYayınları.

Işın, P. M. (2018). Yemeğin kültürel tarihi. YKY.

Kayalı, K. (2006). Sunuş: Peter Burke. M. Küçük (çev.), Fransız Tarih Devrimi Annales Okulu içinde. Doğu Batı Yayınları.

Köksal, O. (n.d.). Türkiye'de beslenme durumunun genel değerlendirmesi ve çözüm için öneriler. Toplum ve Hekim.

Mastrangelo, L. (2015). Community cookbooks: Sponsors of literacy and community identity. Community Literacy Journal, 10(1), 73-86. https://dx.doi.org/10.1353/clj.2015.0021

Mennel, S. (1985). All manners of food: Eating and taste in England and France from the Middle Ages to the Present. Blackwell.

Neuhaus, J. (1999). The way to a man's heart: Gender roles, domestic 1deology and cookbooks in the 1950's. Journal of Social History, 32(3), 529-555.

Samanc1, Ö. (2013). Food studies in Ottoman-Turkish historiography. In K. W. Claflin \& P. Scholliers (Eds.), Writing food history: A global perspective. Berg.

Samanc1, Ö. (2014). Yemek kitaplarında alaturka-alafranga ikiliği. Yemek ve Kültür, 35, 22-27.

Samanc1, Ö. (2019). History of eating and drinking in the Ottoman empire and modern Turkey. In H. L. Meiselman (Ed.), Handbook of eating and drinking (pp. 1-21). Springer.

Tobias, S. M. (1998). Early American cookbooks as cultural artifacts. Papers on Language and Literature, 34(1), 3-18.

Tonner, A. (2008, March 28-30) Favourite cookbooks: Social and individual identity work. Notes from British Sociology Association Conference 2008. https://strathprints.strath.ac.uk/15866/

Wheaton, B. K. (1998). Finding real life in cookbooks: The adventures of a culinary historian. Humanities Research Group, 7. http://www.phaenex.uwindsor.ca/ojs/leddy/index.php/HRG/ article/view/22/27

Wheaton, B. K. (2014). Cookbooks as record for social history. In P. Freedman, J. Chaplin, \& K. Albala (Eds), Food in time and place (pp. 276-295). University of California Press.

Wessell A. (2013). Cookbooks for making history: As sources for historians and as records of the past. M/C Journal, 16(3). http://journal.media-culture.org.au/index.php/mcjournal/article/view/717 
Willian, A., Cherniavasky, M. Cloflin, K. (2012). The cookbook library: Four centuries of the cooks, writers, and recipes that made the modern cookbook (Vol. 35). University of California Press.

Yenal, Z. (1989). The culture and poitical economy of food consumption practices in Turkey (Doctoral dissertation). Binghamton University, Binhamton, NY.

Yenal, Z. (2007). 'Cooking' the nation: Women, experiences of modernity, and the girl's institutes in Turkey. In A. Frangoudaki \& Ç. Keyder (Eds.), Ways to modernity in Greece and Turkey encounters with Europe, 1850-1950 (pp. 191-221). I B Tauris \& Co Ltd. 